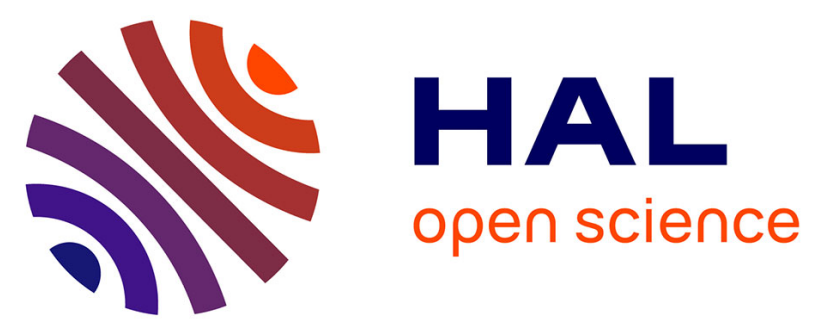

\title{
Clinical and genetic heterogeneity in hereditary spastic paraplegias: From SPG1 to SPG72 and still counting
}

Stephan Klebe, Giovanni Stevanin, Christel Depienne

\section{To cite this version:}

Stephan Klebe, Giovanni Stevanin, Christel Depienne. Clinical and genetic heterogeneity in hereditary spastic paraplegias: From SPG1 to SPG72 and still counting. Revue Neurologique, 2015, 171 (6-7), pp.505-530. 10.1016/j.neurol.2015.02.017 . hal-01161946

\section{HAL Id: hal-01161946 \\ https://hal.sorbonne-universite.fr/hal-01161946}

Submitted on 9 Jun 2015

HAL is a multi-disciplinary open access archive for the deposit and dissemination of scientific research documents, whether they are published or not. The documents may come from teaching and research institutions in France or abroad, or from public or private research centers.
L'archive ouverte pluridisciplinaire HAL, est destinée au dépôt et à la diffusion de documents scientifiques de niveau recherche, publiés ou non, émanant des établissements d'enseignement et de recherche français ou étrangers, des laboratoires publics ou privés. 


\section{CLINICAL AND GENETIC HETEROGENEITY IN HEREDITARY SPASTIC PARAPLEGIAS: FROM SPG1 TO SPG72 AND STILL COUNTING}

Stephan $\mathrm{KLEBE}^{1}$, Giovanni STEVANIN ${ }^{2-5}$, Christel DEPIENNE ${ }^{2,3,5}$

1. Department of Neurology, University Hospital Würzburg, Würzburg, Germany

2. Sorbonne Universités, UPMC Université Paris 06, Paris, France

3. ICM, CNRS UMR 7225, INSERM U 1127, Paris, France

4. Ecole Pratique des Hautes Etudes, Paris, France.

5. Département de génétique et cytogénétique, APHP, Hôpital Pitié-Salpêtrière, Paris, France

Correspondence should be addressed to:

Stephan KLEBE, Department of Neurology, University Hospital Würzburg, Würzburg, Germany. Tel: +49 (0)93120123169. Email: Klebe_S@ukw.de.

Christel DEPIENNE, Institut du cerveau et de la moelle épinière, Hôpital Pitié-Salpêtrière, Paris, France. Tel: +33 (0)1 572746 69. Email: christel.depienne@upmc.fr. 
Hereditary spastic paraplegias (HSPs) are genetically determined neurodegenerative disorders characterized by progressive weakness and spasticity of lower limbs, which are among the most clinically and genetically heterogeneous human diseases. All modes of inheritance have been described, and, due to the recent technological revolution in molecular genetics, 76 different spastic gait disease-loci (SPG) with 59 corresponding spastic paraplegia genes (SPG) have been identified. Autosomal recessive HSP are usually associated with diverse additional features (referred as complicated forms) contrary to autosomal dominant HSP, which are mostly pure. However, the identification of additional mutations and families has considerably enlarged of the clinical spectra and has revealed a huge clinical variability for almost all HSP, and complicated forms have been described for primary pure HSP subtypes, making therefore genotype-phenotype more complex. In addition, the introduction of next generation sequencing (NGS) in clinical practice has revealed a genetic and phenotypic overlap with other neurodegenerative disorders (amyotrophic lateral sclerosis, neuropathies, cerebellar ataxias...) or neurodevelopmental disorders including intellectual disability. This review aims to describe the most recent advances in the field and to provide genotypephenotype correlations that could help making clinical diagnoses of this heterogeneous group of disorders.

Keywords: Hereditary Spastic Paraplegia, Genetic heterogeneity, Clinical variability, Diagnosis. 
Résumé en français

Les paraplégies spastiques héréditaires (PSH) sont des maladies neurodégénératives d’origine génétique caractérisées par une spasticité progressive et une faiblesse des membres inférieurs. Les PSH font partie des affections les plus hétérogènes d'un point de vue clinique mais également génétique, avec plus de 76 loci différents et 59 gènes (SPG) connus rapportés dans la littérature, dont les mutations se transmettent selon tous les modes de transmissions connus. Les PSH autosomiques récessives sont généralement des formes complexes, i.e. associant d'autres symptômes neurologiques ou extra-neurologiques, contrairement aux formes autosomiques dominantes qui ont été décrites comme des formes habituellement pures. Toutefois, un élargissement phénotypique s’est opéré avec la description de familles et mutations additionnelles pour quasiment tous les sous-types de PSH et des formes complexes ont été décrites également dans les formes initialement pures, compliquant ainsi considérablement la visibilité des différentes entités cliniques pour les cliniciens. Par ailleurs, l’introduction du séquençage de nouvelle génération dans la pratique clinique a récemment révélé un chevauchement génétique et phénotypique important entre les PSH et d’autres types de maladies neurodégénératives comme la sclérose latérale amyotrophique, les neuropathies héréditaires, ou encore les ataxies cérébelleuses. Ce chevauchement s'est étendu également à des maladies neuro-développementales comme la déficience intellectuelle. Dans ce contexte, cette revue a pour but de décrire les avancées les plus récentes du domaine et de fournir aux cliniciens un aperçu des corrélations génotype-phénotypes qui peuvent aider à établir un diagnostic moléculaire dans ce groupe de pathologies hétérogènes.

Mots-Clés : Paraplégies spastiques héréditaires, hétérogénéité génétique, variabilité phénotypique, diagnostic. 


\section{Introduction}

Hereditary spastic paraplegias (HSPs) are neurodegenerative disorders characterized by progressive weakness and spasticity of lower limbs. These symptoms are due to progressive degeneration or distal axonopathy of the corticospinal tract, which conducts the nervous information from the cerebral cortex to the spinal cord and allows the control of motor functions. HSP are genetically determined and they are among the most clinically and genetically heterogeneous human diseases. All modes of inheritance (autosomal dominant (ADHSP), autosomal recessive (ARHSP), X-linked (XHSP) and more rarely mitochondrial inheritance) have been described. Due to the considerable progress in molecular diagnostics for neurodegenerative diseases over the last decade, 76 different spastic gait disease-loci (SPG) with 59 corresponding spastic paraplegia genes (SPG) have been identified. This number does not even take into account genes involved in complex forms not referred as HSP or causative genes that are not yet part of the SPG classification ${ }^{1}$.

The onset of HSP ranges from early childhood to more than 70 years. The age at onset depends on the underlying genetic defect, but is also highly variable between family members with a same mutation for almost all HSP subtypes. Besides, the onset of the first symptoms is sometimes difficult to precise and is probably often underestimated, as most HSP forms are slowly progressive and patients complain about their disability a long period of time after the onset. It might therefore be helpful to ask about physical activity in childhood or adolescence because poor performance or lack of interest in sport might indicate a long-lasting motor disturbance. In general, most HSP patients report a slow progression of their motor symptoms. However, the worsening of functional disability is also highly variable between affected individuals, ranging from fairly static, non-worsening cases to inexorable and rapid deterioration. In many patients a functional plateau is reached after a continuous aggravation. The prevalence of HSP has recently been reviewed and estimated to $1.8 / 10^{5}$ for both ADHSP and ARHSP ${ }^{2}$. Most of the 22 reviewed studies were performed in Europe or Asia. Epidemiological studies for rare diseases have to be viewed with a critical eye due to a couple of limitations, including in particular the different methods used for patients' inclusion, diagnosis and classification. These studies do not usually take into account the fact that specific geographic regions can show a cluster of the disease and areas with very low prevalence of the disease are rarely reported. Additionally, founder effects in isolated populations and the level of consanguineous marriages in some populations can contribute to a higher or lower prevalence of ADHSP or ARHSP in specific geographic regions ${ }^{3}$. Due to these limitations, the prevalence could easily be overestimated or underestimated depending 
on the population.

The clinical classification, based on the historic description by Anita Harding in 1983 distinguishes between pure and complex forms of HSP. Patients with pure HSP show isolated pyramidal signs, i.e. brisk reflexes, Babinski sign, spasticity, and motor deficit, which can be associated with sphincter disturbances and deep sensory loss. The severity of the motor symptoms is assessed by the Spastic Paraplegia Rating Scale (SPRS) ${ }^{4}$. Complex forms consist of a multitude of clinical entities in which HSP is associated with variable combinations of other neurological or extra-neurological signs, such as cerebellar ataxia, dysarthria, mental retardation, peripheral neuropathy, optic atrophy, retinitis pigmentosa, hearing loss, or thin corpus callosum ${ }^{5}$.

Recently, the advances in molecular diagnosis have revealed a large clinical and genetic overlap within different HSP subtypes ${ }^{7}$, and between HSP and other neurodegenerative diseases like hereditary ataxia, amyotrophic lateral sclerosis (ALS) ${ }^{8}$, primary lateral sclerosis $(\mathrm{PLS})^{9}$, Charcot-Marie-Tooth disease $(\mathrm{CMT})^{10}$ and elusive clinical syndromes like BoucherNeuhäuser and Gordon Holmes or Kjellin syndrome ${ }^{11-13}$ (Figure 1). Although the distinction between pure and complex forms serves in daily routine, this classification could lead to overlook the cause of the disease since pure and complex phenotypes have been described for almost all HSP subtypes. In addition, a single or a few families have been described in many newly described HSP forms. The experience of the last two decades has taught us that the phenotypical spectrum is usually broadened when additional mutated patients are reported. The current challenge for neurologists is then to link the clinical and molecular results to a specific neurogenetic disease. Discussions with specialized movement disorder centers and geneticists are thus becoming important, especially in the time of next-generation sequencing (NGS) and gene panel analyses. In this context, this review will focus on a rational clinical based diagnostic of the heterogeneous genetic group of HSP. We will try to guide the reader through the most relevant phenotype/genotype correlations for diagnostic clues and to have a red line for HSP diagnostics.

\section{Clinical diagnosis of HSP and differential diagnoses}

The elicitation of family history is a crucial step in HSP diagnosis. It is often more difficult to clinically and genetically assess patients without family history or without reliable information. In these sporadic cases, HSP is essentially a diagnosis of exclusion.

The technical examinations in HSP patients comprise a magnetic resonance imaging (MRI) of the head and the spinal cord, which usually shows no particular damage, a normal lumbar 
puncture and an electrophysiological examination, including transcranial magnetic stimulation (TMS) and somatosensory evoked potentials (SEP) of the upper limbs (UL) and lower limbs (LL), nerve conduction studies and electromyography (EMG). TMS of the LL typically shows an elevated cortical motor threshold, reduced amplitudes and a prolonged central motor conduction time (CMCT). However, TMS of the LL in pure HSP forms can also be normal ${ }^{14,15}$, due for example to primarily axonal damages or selective affection of thinner motoneurons and other motor pathways (i.e. reticulospinal or vestibulo-spinal tracts) that omit the fastest conducting thick fibers investigated by TMS. SEP of the LL are frequently prolonged or even absent ${ }^{16,17}$, whereas SEP of the UL are often normal in pure HSP cases ${ }^{17}$. The UL are typically spared from clinical symptoms especially in pure forms, even after several decades of disease duration. Nonetheless, the UL often display hyperreflexia and conflicting electrophysiological results have been shown ${ }^{15,18}$. In a recent published electrophysiological study, TMS of the UL showed pathological results in about one third of the patients ${ }^{15}$. Clinical signs of peripheral neuropathy are frequently observed with affected sensory and motor nerves of the UL, LL or both ${ }^{15}$ and reflects the clinical overlap between HSP and CMT. An ophthalmological examination including a funduscopy and optical coherence tomography (OCT) should be part of the examination if possible to detect subclinical optic atrophy (see SPG7). Regarding the bladder dysfunction, two systematic studies have revealed a urinary dysfunction in up to $78 \%$ of patients with urgency or incontinence as the most dominant complaint in HSP patients with a pure phenotype ${ }^{19,20}$. HSP patients do not seem to have a higher risk of developing upper urinary tract complications even after a long-term follow up of two decades ${ }^{20}$.

In sporadic patients, additional evaluation includes the analysis of very long chain fatty acids (VLCFA), white cell enzymes, plasma amino acids, lipoprotein analysis, vitamin B12, homocysteine, methionine, vitamin E, copper, ceruloplasmin, treponema pallidum, human Tcell leukemia virus 1 (HTLV1) and HIV. Treatment by low doses of L-dopa can also be valuable to rule out the possibility of GTP cyclohydrolase I deficiency (DOPA-responsive dystonia, due to mutations in GCH1), since patients with this disorder sometimes present with spastic paraplegia at the beginning of the disease ${ }^{21}$. In young onset forms and obvious autosomal-recessive cases a neurometabolic screening (Krabbe disease, metachromatic leukodystrophy, GM1-gangliosidosis, GM2-gangliosidoses Tay Sachs and Sandhoff, Gaucher disease) should be considered and excluded by serum and/or cerebrospinal fluid (CSF) diagnostic. An overview of the differential diagnoses of HSP is given in Table 1. 


\section{Spastic Paraplegia Genes (SPGs)}

The first SPGs were identified in the late 1990s using genome-wide linkage in the largest families, followed by cloning of the causal gene. This approach, which has usually taken several years, was mainly based on candidate gene prioritization. In several cases, a genomic region has been reported but the corresponding gene still remains unknown. For this reason, a total of 76 genomic regions and 59 genes have been described to date in HSP.

In the last few years, an acceleration of gene discovery consecutive to the development of new technologies, including microarrays and next generation sequencing (NGS), has occurred. These technologies, which respectively allow detecting copy number variations (CNVs) and small variants present all over the genome, have completely revolutionized the strategies used for gene identification, making in particular possible the analysis of small families and sporadic cases at an individual scale. The NGS techniques commonly used for research or diagnostic purposes are whole exome sequencing (WES, i.e. sequencing of all the coding regions of a genome) and sequencing of selected genes (gene panels). These techniques have led to the identification of many new genes in which mutations are extremely rare and account for only a few families worldwide. Another consequence of the use of NGS in clinical practice was the description of mutations in known genes associated with unusual phenotypes and the demonstration that there is a continuum between HSP and other neurodegenerative disorders (Figure 1).

Nineteen SPGs follow an autosomal dominant mode of inheritance and are more commonly associated with pure or mixed (i.e. pure and complex) forms of HSP. Among those, 11 genes have been identified (Table 2). These genes include SPAST (SPG4), ATL1 (SPG3), REEP1 (SPG31), KIF5A (SPG10), NIPA1 (SPG6), KIAA0196 (SPG8), RTN2 (SPG12) and BSCL2 (SPG17). SPG4 is the main dominant form, accounting for $40 \%$ of ADHSP families. The frequency of all other ADHSP subtypes is much lower, ranging from $5-10 \%$ to less than $1 \%$. The list of published ADHSP genes also includes HSPD1 (SPG13), ZFYVE27 (SPG33) and SLC33A1 (SPG42) although those genes were not validated by further studies and it therefore remains controversial whether mutations of these genes are truly pathogenic.

The field of the ARHSP has recently known a real revolution, with 15 new genes identified in a single study ${ }^{1}$. To date, 52 different loci and 45 genes with AR inheritance have been described (Table 2). Contrary to ADHSP, ARHSP are mostly complicated forms and are very diverse from one subtype to another regarding both age at onset, disease evolution and the nature of the associated clinical features. In extreme cases such as Troyer syndrome (SPG20) or Mast syndrome (SPG21), pyramidal signs only constitute a sign among many other clinical 
characteristics (see Table 2). The main SPGs causing ARHSP to date are SPG7, SPG11, and SPG15. SPG7, encoding the mitochondrial paraplegin protein, is the first ARHSP gene identified in $1998^{22}$. Mutations in SPG11 and SPG15 cause a similar complex HSP form characterized by progressive corpus callosum atrophy concomitant with a cognitive decline, which are amongst the most frequent features associated with ARHSP ${ }^{7,23,24}$.

X-linked HSP subtypes are more exceptional, with only 5 loci and 3 genes reported so far (Table 2). Like ARHSP, mutations in X-linked genes usually cause early-onset, complex phenotypes, such as MASA or CRASH syndromes (both related to mutations in L1CAM/SPG1), Pelizaeus-Merzbacher disease (due to mutations in PLP1/SPG2), and AllanHerndon-Dudley syndrome (due to mutations in SLC16A2/SPG22), but their expression is usually restricted to hemizygous males.

An interesting recent observation is the increasing evidence that mutations in some SPGs can be inherited according to different modes of inheritance: this is for example the case of ATL1 (SPG3), in which recessive mutations causing HSP have recently been described ${ }^{25}$; REEP2 (SPG72), in which both a dominant mutation leading to a dominant negative effect on the WT allele and a recessive mutations causing a loss of function have been reported ${ }^{26}$; and KIF1A (SPG30), in which recessive mutations were initially described, while de novo dominant mutations associated with complex HSP including cognitive impairment were recently reported $^{27,28}$.

Finally, mutations in mitochondrial genes, such as $M T-A T P 6^{29}$ or $M T-T I^{30}$, could occasionally account for patients with pure or complex forms of HSP depending on the heteroplasmy rate and affected tissues. These unusual forms could be easily overlooked unless the presentation of the disease, usually very variable from one family member to the other, suggests a mitochondrial involvement in at least some of them.

\section{Phenotype/genotype correlations in HSP}

The objective of the following section is to focus on the frequent and well-characterized HSP subtypes, which are the most relevant forms in daily clinical practice, and to establish correlations according to the clinical presentation. For the complete list of HSP subtypes described to date, please refer to Table 2.

\subsection{Pure or mixed HSP with AD inheritance}

Pure HSP consists of clinical signs of an upper motor neuron syndrome affecting the LL, which can further be associated with electrophysiological alterations, sphincter disturbances 
and deep sensory loss. The MRI and lumbar puncture usually show no specific abnormalities in pure HSP patients. The clinical signs include spasticity, an extensor plantar response, hyperreflexia, crossed adductor signs and a slight weakness most prominent in iliopsoas, hamstring and tibialis anterior muscles. With the exception of SPG17, all ADHSP with a known gene have initially been described as pure forms. However, the identification of additional mutated families has systematically revealed that most HSP subtypes can also occur as complicated phenotypes in some individuals. There are two main nonexclusive reasons accounting for this variability: the patients could present with a pure form at the beginning of the disease and evolve toward a complicated phenotype over time. It is also possible that genetic or environmental modifiers play a determinant role in determining the age at onset, presentation and evolution of the disease. The different pure / mixed ADHSP presented below are sorted according their known prevalence.

\section{SPG4 (Spastin)}

SPG4 is by far the most frequent ADHSP subtype, especially in patients with a pure phenotype, accounting for $\sim 40 \%$ of ADHSP and $10-20 \%$ of apparently sporadic cases ${ }^{5,31-33}$. The mean age at onset is typically between the third and fourth decade of life $\mathrm{e}^{34,35}$, although symptoms may start as early as infancy or as late as 70 years, and vary even between members of a same family. Usually, SPG4 patients show a slowly progressive disorder, many of them being able to walk several decades after the first symptoms. Besides the clinically affected LL, UL hyperreflexia, decreased vibration sense, and a slight muscle wasting in the lower limbs are consistently found. Some mutation carriers can remain unaffected or very mildly affected all their lives. TMS of the UL is typically normal ${ }^{15,18}$ and TMS of the LL is normal in up to $48 \%{ }^{14,15}$. The axonal integrity of corticospinal projections to the UL in SPG4 patients has been investigated using the triple stimulation technique (TST) ${ }^{18}$ and has not shown pathological changes. TST is considered to be two or three times more sensitive than standard TMS procedures to detect corticospinal conduction deficits and is especially suited for the detection and quantification of small changes of central motor conduction ${ }^{18}$. A slightly delayed P40 latency of the SEP has often been reported for the LL, contrary to the SEP of the $\mathrm{UL}$, which is normal ${ }^{15}$.

SPG4 HSP is caused by mutations in SPAST, encoding spastin, a member of the AAA family of ATPases ${ }^{33}$. All types of mutations (missense, nonsense, splice site mutations, small deletions and insertions, as well as rare large scale deletions or duplications) have been identified. This large spectrum is compatible with haploinsufficiency (i.e. loss of function of 
one allele) as the main pathogenic mechanism. Mutations have been reported in all exons of the gene with the exception of exon 4, which is alternatively spliced in blood and brain. Recurrent mutations are exceptional, and, with only a few exceptions, missense mutations are always located in the AAA cassette.

\section{SPG3 (Atlastin)}

SPG3 is characterized by a clinically pure phenotype that progresses very slowly over time ${ }^{36}$, ${ }^{37}$. It is the most frequent ADHSP in patients with a disease onset $<10$ years ${ }^{37}$, 38, with a mean age at onset of 5 years ${ }^{37}$. Very occasionally, a late onset or complex or more severe phenotypes have been reported in SPG3 patients ${ }^{39-47}$. SPG3 HSP is due to mutations in ATL1, encoding atlastin 1, a dynamin-related GTPase. Most of the dominant mutations described so far are missense mutations supposed to lead to a gain of function of atlastin $1^{48,49}$.

\section{SPG31 (REEP31)}

SPG31 is responsible for approximately 2-8\% of ADHSP depending on the population ${ }^{35,50-53}$. The symptoms of the disease usually appear in the first two decades of life. However, patients with an adult-onset also exist and the age at onset varies between affected family members. Like SPG4 individuals, patients can remain unaffected, even at advanced ages ${ }^{50,52}$. Although most SPG31 patients have a pure phenotype, complicated forms including lower motor neuron involvement mimicking a Silver syndrome and abnormal white matter signals have been described (see 4.4) 50, 52, 54. Mutations in REEP1 are of all types (missense or truncating mutations) and exon deletions have also been reported ${ }^{35,50-53}$.

\section{SPG10 (KIF5A)}

SPG10 accounts for 2-10\% of AD families and sporadic patients in Europe $\mathrm{e}^{55-58}$. The age at onset is usually late (>35 years) although early infantile onset has also been described ${ }^{58,59}$. The phenotype of SPG10 has first been classified as pure ADHSP ${ }^{60}$. However, in European countries, SPG10 accounts for up to $10 \%$ of complicated ADHSP cases ${ }^{57}$. The complicated phenotype of SPG10 patients is often associated with CMT2 and Silver syndrome ${ }^{57,61}$ (see 4.4). The phenotype has recently broadened to include sensory spinal cord-like syndrome, dysautonomia, severe axonal polyneuropathy and symmetric cerebral demyelination and spinal cord atrophy on the MR in some patients ${ }^{62}$.

Like ATL1, mutations in KIF5A, encoding the neuronal kinesin 5A heavy chain involved in anterograde axonal transport, are mainly missense mutations located in the motor domain of 
the $\operatorname{protein}^{55-58,63}$.

\section{SPG6 (NIPA1)}

Mutations in NIPA1 are a rare cause $(<1 \%)$ of $\mathrm{ADHSP}^{64,65}$. In the literature, less than 20 pedigrees with NIPA1 mutations have been reported with a worldwide distribution ${ }^{65-68}$. The mean age at onset varies between early childhood and late adulthood ${ }^{65}$. Most of the patients have a pure phenotype with a slow disease progression ${ }^{65,69}$ but an intrafamilial clinical heterogeneity also exists for this HSP subtype ${ }^{65,69}$. In some families, a mild memory deficit has been reported. Only a few recurrent missense mutations have been identified in NIPA1. Interestingly, NIPA1 is located on chromosome 15, in a region with variable copy number. Deletion of the four genes comprised in this region (including NIPA1) predisposes to various neurodevelopmental disorders ${ }^{70}$ but is almost never associated with HSP, indicating that haploinsufficiency of NIPA1 does not cause HSP.

\subsection{Pure or mixed HSP with AR inheritance}

\section{SPG7 (Paraplegin)}

The frequency of SPG7 HSP, initially thought to be rare ${ }^{71}$, has recently been reevaluated and might be as high as $8-10 \%$ of all HSP including sporadic cases ${ }^{35}$. This change is partly due to the fact that a recurrent missense variant (Ala510Val), first considered as a polymorphism, finally turned out to be pathogenic ${ }^{72-74}$. SPG7 HSP is slowly progressive and usually pure at the beginning of the disease, with an age at onset ranging from 10 to 63 years ${ }^{71-73,75-77}$. An onset in childhood or adolescence is rare ${ }^{73}$, which is quite uncommon for a recessive disorder. During the course of the disease, atrophy of the cerebellum observed by MRI, followed or accompanied by cerebellar signs frequently appear: these signs can be observed in up to $57 \%$ of the patients ${ }^{71-73,75,76}$. Another feature characteristic of SPG7 HSP is bilateral optic disc pallor, which has been observed in several SPG7-positive families $22,73,77,78$. A very useful tool to determine optic neuropathy is optical coherence tomography (OCT). In a recent study, all SPG7-positive patients who underwent OCT had detectable pathology of the optic nerve ${ }^{73}$. The identification of a dominant SPG7 mutation segregating with clinically isolated optic neuropathy in a large multigenerational pedigree supports the view that the loss of retinal ganglion cells in patients with hereditary spastic paraplegia with SPG7 mutations is not coincidental $^{73}$. Therefore, patients might have a pure phenotype on examination, but in fine, if cerebellar atrophy is detected by brain MRI or optic neuropathy by OCT, they have to be 
reclassified to complex HSP. The diagnostic accuracy can hence be increased if patients are selected on the basis of their phenotype for SPG7 testing ${ }^{73}$.

Mutations in SPG7 are of all types, also including large exon or whole gene deletion ${ }^{22,71,73}$. Several mutations such as p.Ala510Val and p.Arg485_Glu487del are recurrently found. Interestingly, heterozygous mutations in SPG7 were associated with late-onset neurologic signs including cerebellar signs, neuropathy or gait instability ${ }^{73}$.

\section{SPG5 (CYP7B1)}

SPG5 is an ARHSP with a frequency up to 8\% of ARHSP families and 3\% in apparently sporadic cases ${ }^{79,80}$. Age at onset shows both an interfamilial and intrafamilial variability, with a range from early childhood to the $5^{\text {th }}$ decade of life ${ }^{79-81}$. Most SPG5 patients show a slowly progressive pure form, but complicated courses with/or without periventricular and subcortical white matter lesions at brain MRI have been reported in patients with a long disease duration $^{79,80,82}$. A cerebellar involvement and/or optical atrophy have been described in a few patients ${ }^{79-82}$. Electrophysiological investigations have reported profound dorsal column deficits with severe disturbed SEP of the UL and LL with normal nerve conduction study and EMG ${ }^{16}$. SPG5 is due to nonsense or missense mutations in the CYP7B1 gene, encoding the oxysterol 7-alpha-hydroxylase, a steroid-metabolizing enzyme belonging to the cytochrome P450 family involved in bile acid and neurosteroid biosynthetic pathways. As a consequence of the loss of function of this enzyme, an accumulation of 27-hydroxycholesterol occurs in the serum and $\mathrm{CSF}^{83}$. The aforementioned molecule may serve as therapeutic target and could act as first biomarker in this HSP subtype.

\section{SPG30 (KIF1A)}

SPG30 is a rare ARHSP form with an age at onset between 10 and 39 years and a slow disease progression ${ }^{84,85}$. Cerebellar signs, or cerebellar atrophy and axonal sensorimotor peripheral neuropathy are frequently associated signs. Recently, autosomal dominant mutations mostly occurring de novo were identified in patients with a more complex and severe phenotype including intellectual deficit, axonal neuropathy and cerebellar atrophy ${ }^{27,86}$.

\section{SPG49/SPG56 (CYP2U1) and SPG28 (DDHD1)}

SPG49 (nomenclature source: HUGO Gene Nomenclature Committee (HGNC)) or SPG56 (nomenclature source: National Center for Biotechnology Information (NCBI)) is a rare ARHSP with very early onset (birth to age 8 years) that can present either as pure or complex 
forms. Contrary to other HSP, UL are also frequently affected. Additional features in complicated forms include dystonic posturing of the upper limbs, cognitive impairment, subclinical axonal neuropathy, thin corpus callosum, white-matter abnormalities, and/or calcification of the basal ganglia ${ }^{87}$. SPG28 is a rare early-onset, slowly progressive and usually pure form. Some patients also have distal sensory impairment ${ }^{87}$. SPG49/56 is caused by biallelic mutations in CYP2U1, a member of the P450 enzyme family, while SPG28 is due to mutations in DDHD1, which encodes a lipase that catalyzes degradation of phosphatidic acid. Both enzymes are involved in fatty-acid metabolism.

\subsection{HSP with abnormalities in neuroimaging}

Neuroimaging abnormalities in the MRI are commonly present in complicated HSP forms. The most frequent abnormality is a thin corpus callosum (TCC) present in about one-third of ARHSP index cases ${ }^{24}$. Other MRI abnormalities frequently associated with HSP include white matter lesions (WML) or white matter abnormalities (WMA), and cerebellum atrophy, often concomitant with a cerebellar phenotype.

A TCC has been reported in at least 15 different HSP subtypes, and is almost always associated with cognitive deterioration or intellectual disability (ID) ${ }^{35}$. By far, the most frequent HSP form associating TCC, cognitive impairment and/or WML is the SPG11 ARHSP subtype, followed by SPG15 ${ }^{88,89}$, SPG49/56 ${ }^{87}$ and SPG46 ${ }^{90}$. TCC and WML have also been observed in patients with SPG $21^{91}$, SPG $44^{92}$, SPG $47^{93}$, SPG$^{9} 4^{94}$ and SPG63 HSPs ${ }^{1}$. An agenesis of the corpus callosum (ACC) has been reported in the SPG1 X-linked HSP ${ }^{95}$ and the recently published SPG67 ARHSP ${ }^{1}$.

WML are frequent in complicated phenotypes and are occasionally also described in pure HSP forms (e.g. SPG4, SPG5). The clinical overlap between HSP and other forms of metabolic and neurodegenerative diseases with specific WML has become evident since the identification of neurodegeneration with brain iron accumulation (NBIA) on MRI in patients with FA2H (SPG35) mutations ${ }^{96}$ (Figure 1).

\section{SPG11 (Spatacsin)}

The SPG11 gene, encoding spatacsin, has been identified in $2007^{97}$. SPG11 mutations are responsible for up to $60 \%$ of patients with TCC and cognitive impairment and $4.5 \%$ of cases with spastic paraplegia, cognitive impairment and WML without TCC ${ }^{88}$. Overall, SPG11 mutations account for approximately $20 \%$ of ARHSP $^{88,98}$. The age at onset ranges from early childhood to the third decade of life, although late onset is more occasional ${ }^{88,97,99,100}$. TCC 
with or without WML is present in the vast majority ( $>90 \%)$ of mutated individuals ${ }^{88,97}$. ID or cognitive deterioration are observed in $>80 \%$ of SPG11 patients ${ }^{88,97}$. Other frequent associated clinical signs include axonal sensory-motor neuropathy, cerebellar symptoms (nystagmus, dysarthria, saccadic pursuit) and, to a lesser extent, extrapyramidal symptoms and retinopathy ${ }^{13,70,88,101}$. The progression of motor symptoms in SPG11 HSP is more severe than in pure phenotypes since two-third of patients are wheelchair bound or need assistance for walking after mean disease duration of 15 years $^{88}$. Several studies have shown that some SPG11 patients can present with juvenile ALS (jALS, also classified as ALS5) and that 40\% of families with jALS and long-term survival (>25 years after disease onset) are SPG11 positive $^{8,102}$. Strikingly, these SPG11 positive ALS patients have bulbar symptoms, clinical signs typical of ALS, and normal nerve conduction analyses, but no TCC, WMA and/or cognitive deficits. However, the existence of an intrafamilial phenotypic heterogeneity with an atypical ALS and a classical HSP-TCC phenotype in some families is very evocative of SPG11 mutations ${ }^{8,102}$.

With rare exceptions, SPG11 mutations all introduce a premature termination codon (i.e. nonsense mutations, splice site mutations, frameshifts and microrearrangements deleting one or more exons) leading to the absence of the spastacsin protein in the patients’ cells.

\section{SPG15 (Spastizin)}

SPG15, initially identified as a complicated ARHSP associated with pigmentary maculopathy (Kjellin syndrome) ${ }^{11,103}$, is due to mutations in ZFYVE26, encoding spastizin. ZFYVE26 mutations are responsible for $\sim 12 \%$ of subjects with ARHSP and TCC and $\sim 4 \%$ of all ARHSP $^{89}$. Age at onset ranges from 4 to 18 years $^{89,104}$. Brain imaging shows TCC and white matter signal abnormalities in about $80 \%$ of SPG15 patients and cerebellar atrophy in 25\% of the cases ${ }^{89}$. A clinical distinction between SPG11 and SPG15 is difficult as both ARHSP are associated cognitive impairment and peripheral axonal neuropathy and a similar disease progression. However, SPG15 patients suffer more often from cerebellar signs and hearing loss $^{89,104}$. Like those in SPG11, biallelic mutations in ZFYVE26 lead to a loss of function of the gene.

\subsection{HSP associated with peripheral motor neuropathy and/or distal muscle atrophy}

The differential diagnosis of HSP versus amyotrophic lateral sclerosis (ALS) is often based on the observation of an affected lower motor neuron in ALS. There is growing evidence in the literature that the combination of upper and lower motor tract impairment by itself is not 
indicating only of ALS but is a common feature of HSP as well. As discussed earlier (see 4.2), SPG11 is a good example of ARHSP in which mutations can also cause juvenile ALS $(\mathrm{ALS} 5)^{8}$. Mutations in the same gene may lead to a damage of the upper motor neuron, peripheral motor neuron or sensory nerves, explaining the variability of the phenotype, which can appear as HSP and/or spinal muscular atrophy (SMA), distal hereditary motor neuropathy (dHMN), hereditary sensory neuropathy (HSN), hereditary sensory autonomic neuropathy (HSAN) or CMT. Examples of genes associated with such variability are ALSIN (ALS2) ${ }^{105}$, 106, SETX (ALS4) ${ }^{107,108}$, BSCL2 (SPG17; dHMN-V, see below) ${ }^{109-111}$, KIF1A (SPG30; HSAN-II) ${ }^{112,113}$, REEP1 (SPG31; Silver like syndrome, dHMN-V) 52-54, 114, KIF5A (SPG10; Silver like syndrome; CMT2) ${ }^{57,61}$ ATL1 (SPG3; HSN-I) ${ }^{39,40}$, and NIPA1 (SPG6) (although the association with ALS is exceptional) ${ }^{115}$. An atrophy of the small hand muscles or a wasting of the UL has been reported for the complicated HSP forms SPG10, SPG17, SPG22, SPG30, SPG38 and SPG43 ${ }^{35}$.

\section{SPG17 (BSCL2)}

The complicated SPG17 ADHSP, also known as Silver syndrome, is caused by two mutations in BSCL2, encoding seipin ${ }^{110}$. These two mutations (p.Asn88Ser and p.Ser90Leu) affect glycosylation of seipin and result in aggregate formation leading to neurodegeneration ${ }^{116}$, contrary to mutations leading to a loss of function of the gene, which cause two AR allelic disorders: congenital generalized lipodystrophy type 2 and progressive encephalopathy with or without lipodystrophy ${ }^{109,117}$. Silver syndrome was first described in 1966 in two families with spastic paraplegia in which a wasting and atrophy of the small hands muscles was the first and most marked manifestation ${ }^{110,118}$. The phenotype has later been extended to dHMN$\mathrm{V}, \mathrm{CMT}$ and even to pure HSP${ }^{111,119,120}$. A reduced penetrance and patients with only subclinical signs have been described ${ }^{120}$. The age at onset is again variable and ranges from 2 to 60 years ${ }^{111,119-122}$. BSCL2 mutations could be the most common cause of $\mathrm{dHMN}^{122}$. The phenotype and the disease progression seem to depend on the mutation. Patients with the p.Asn88Ser mutation usually have a rather slow progression, more often a dHMN phenotype and relatively mild impact on daily live functioning despite an onset of disease in the first or second decade of life $\mathrm{e}^{120,121}$. Patients with the p.Ser90Leu mutation mostly have a prominent amyotrophy of the intrinsic hand muscles in association with a marked spasticity of the lower limbs and the presence of additional pyramidal tract signs ${ }^{122}$, corresponding to Silver syndrome. A detailed electrophysiological study in four Austrian families has revealed that Silver syndrome is not only caused by impairment of upper motor neurons but is also due to a 
peripheral motor neuropathy closely resembling clinically to $d H M N-V^{123}$. This study has reported a conduction block of the tibial nerve in two patients ${ }^{123}$, which we have also observed in one SPG17 patient (unpublished data). This observation suggests that SPG17 should be included in the diagnostic workup of Multifocal Motor Neuropathy (MMN). The aforementioned implicates that a careful and detailed family history in MMN is of great importance.

\subsection{HSP and cerebellar ataxia}

The association of an upper motoneuron syndrome and cerebellar signs (dysarthria, nystagmus, coordination problems in finger-nose dysmetria, tandem walk ect.) and/or cerebellar atrophy on MRI imaging is common in complicated HSP subtypes. The ataxia can be the most prominent sign as in SPG46 (GBA2) ${ }^{90,124}$, SPG58/SAX2 (KIF1C) ARHSP ${ }^{1,125}$ and ARSACS $(S A C S)^{126,127}$, or only an associated sign, such as in SPG1 (L1CAM), SPG7 (see 4.2), SPG11, SPG15 (ZFYVE26), SPG26 (B4GALNT1), SPG30 (KIF1A), SPG31 (REEP1), SPG44 (GJC2), SPG49/SPG56 (CYP2U1), SPG50 (AP4M1), SPG54 (DDHD2) SPG66 (ARSI), and SPG67 (PGAP1) ${ }^{35}$.

One important differential diagnostic of HSP with cerebellar ataxia is Friedreich Ataxia (FRDA). FRDA is the most common autosomal recessive ataxia in Europe with an estimated prevalence if 3-4/10 $0^{528,129}$. FRDA can mimic HSP in particular in patients with a late onset (>25 years). In these patients, an affected upper motoneuron syndrome might be the most prominent sign at the beginning of the disorder.

The classification between HSP associated with cerebellar involvement and spastic ataxias (SPAX) is sometimes confusing and the reason why some HSP are not classified as SPAX and vice versa is not obvious. Autosomal recessive spastic ataxias include ARSAL (MARS2; SPAX3) $)^{130}$ and ARSACS (SACS; SPAX6) ${ }^{127}$. Some genes even belong different classifications, such as the autosomal dominant spastic ataxia due to AFG3L2 mutations $(\mathrm{SPAX} 5=\mathrm{SPG} 28)^{131}$, or the recently published ARHSP due to KIF1C mutations (SPG58 = SPAX2) ${ }^{125,132}$. In addition, a cerebellar involvement has also rarely been reported for primarily pure phenotypes including SPG3, SPG4 and SPG6.

\subsection{HSP and intellectual deficiency (ID)}

As previously discussed in section 4.3, the most frequent cause of HSP and intellectual disability (ID) known so far is mutations in SPG11 ${ }^{7}$. Cognitive impairment in SPG11 HSP is usually noticed in childhood and progresses insidiously to severe functional disability of a 
frontal type over a period of 10-20 years ${ }^{133}$. An age at onset in early childhood and/or delayed psychomotor development exists in some individuals ${ }^{134}$, although motor signs preceding mental deterioration can appear much later in other individuals.

The association of HSP and ID (or cognitive decline) is frequent in complicated ARHSPs, including SPG15 (ZFYVE26), SPG18 (ERLIN2), SPG20 (KIAA0610), SPG21 (ACP33), SPG26 (B4GALNT1), SPG35 (FA2H), SPG44 (GJC2), SPG46 (GBA2), SPG47 (AP4B1), SPG48 (AP5Z1), SPG49 (TECPR2), SPG50 (AP4M1), SPG51 (AP4E1), SPG52 (AP4S1), SPG53 (VPS37A), SPG54 (DDHD2), SPG55 (C12ORF65), SPG49/SPG56 (CYP2U1), SPG58 (KIF1C), SPG59 (USP8), SPG64 (ENTPD1), SPG65 (NT5C2), SPG69 (RAB3GAP2), and the X-linked HSP SPG1 (L1CAM), SPG2 (PLP1), SPG22 (SLC16A2) and is also present in homocystinuria due to methylenetetrahydrofolate reductase deficiency (mutations in the MTHFR gene), a disorder potentially treatable by betaine supplementation ${ }^{135}$.

In addition, recurrent duplications or triplications of a region comprising 16 genes (including RPL10, ATP6AP1 and GDI1) on chromosome Xq28 have been shown to cause HSP and ID whose severity is dependent on the copy number ${ }^{136}$. More generally, the association of HSP and ID is an indication to search for genomic rearrangements using microarrays.

\section{Molecular genetic testing of HSP}

\subsection{Identification of the causative gene/mutation in a family}

Until very recently, molecular screening of SPGs in index cases was done sequentially (i.e. one gene at a time) using Sanger Sequencing. The choice of the tested genes was driven by the phenotype (pure/complex forms), age at onset of the first symptoms and mode of inheritance observed in the family. For example, in patients with pure ADHSP, molecular testing of SPAST was prioritized in patients with an age at onset $>10-15$ years whereas ATL1 was first analyzed in patients with early-onset ( $<10$ years). If the analysis of these genes was negative, other genes (REEP1, KIF5A, NIPA1 ect.) were further screened. Since Sanger sequencing does not allow detecting heterozygous microrearrangements altering the gene such as exon deletions, a method measuring the quantity of each exon (Multiplex ligationdependent probe amplification / MLPA, quantitative PCR) was recommended in parallel to Sanger sequencing.

However, the introduction of NGS has transformed the strategies used for molecular testing of HSP. By drastically reducing the cost of DNA sequencing and allowing fast and efficient sequencing of millions or even billions of bases in a single experiment, the new sequencers now offer the possibility of analyzing all genes involved in a pathology at the same time. This 
method, referred to as gene panel analysis, has become available in diagnostic laboratories and tends to totally replace Sanger sequencing ${ }^{137,138}$.

\subsection{Molecular testing in sporadic cases}

As discussed in section 2, HSP is mainly a diagnosis of exclusion in patients with spastic paraplegia or spastic paraparesis without family history of the disease. After exclusion of nongenetic causes and other genetic disorders that can mimic HSP, molecular testing of HSP genes has to be considered in sporadic HSP cases, especially if age at onset is early and before the age of 50 years. Many different reasons account for the absence of family history: incomplete penetrance, genealogical censure ${ }^{34}$, and more rarely de novo mutations for dominant forms, or absence of recurrence of an AR or X-linked disease in small families. The main genetic causes of isolated HSP patients are mutations in $S P A S T^{31}, S P G 7^{71,73}, K I 5 F A^{57}$ and $C Y P 7 B 1^{79}$, and more rarely, mutations in REEP1 and ATL1 (personal communication). Mutations in SPG11 are also very frequent in sporadic HSP-TCC ${ }^{88}$.

\subsection{Genetic counseling and molecular testing of at-risk individuals}

Since the first symptoms of many HSP subtypes, especially those of AD inheritance, can occur at any time from infancy to adulthood, asymptomatic individuals may be carrier of a mutation and therefore at-risk to develop HSP. The proportion of mutated individuals who exhibit clinical symptoms is called penetrance. In ADHSP, penetrance is typically incomplete and age-dependent, i.e. mutated individuals have a risk of developing HSP symptoms increasing with age.

The identification of the causative mutation in a family has thus important consequences for family members: it allows precisely appraising the risk of each of them, and performing a predictive molecular test in adult at-risk asymptomatic individuals who wish to know their status. In addition, the possibility of performing prenatal diagnosis can be considered for the more severe forms.

\section{Pathophysiological mechanisms underlying HSP}

The identification of SPGs has been a crucial step to understanding the pathophysiological mechanisms involved in HSPs. Although many different genes have been identified, it is now recognized that they encode proteins functioning in a limited number of cellular pathways, including axonal transport, intracellular trafficking, mitochondrial function, lipid metabolism and developmental processes and myelination ${ }^{139}$ (Figure 2). Moreover, many of the encoded 
proteins altered in HSP interact together or belong to a large interconnected network ${ }^{1}$.

HSP is due to a length-dependent distal axonopathy of the fibers constituting the corticospinal tract. Since the axons of the upper motor neuron are the longest of the human body, it has been postulated that the processes impairing paths or connections between the cellular body and the axon terminals (synapses) will lead to a dysfunction of the axon and therefore be pathogenic. Cargo protein regularly travel at high velocities on specific cytoskeletal structures (microtubules) within the axon to deliver proteins and intracellular organelles such as elements of the endoplasmic reticulum (ER), mitochondria, endosomes, or synaptic vesicle precursors from the cell body towards the axonal terminals (anterograde transport) or vice versa (retrograde transport). Kinesins are the main microtubule motor proteins involved in anterograde transport. SPG10 (KIF5A), SPG30 (KIF1A) and SPG58 (KIF1C) are all HSP subtypes due to mutations in kinesin chains ${ }^{55,125,139,140}$. For example, missense mutations in KIF5A located in the kinesin motor domain have been shown to impair microtubule affinity or gliding properties on microtubules or both ${ }^{63}$. Spastin (SPAST, SPG4) also binds microtubules and regulate their dynamics and organization by performing ATP-dependent severing ${ }^{141,142}$. Spastin interacts with atlastin 1 (ATL1, SPG3) ${ }^{143,144}$, REEP1 (SPG31) ${ }^{145}$, and reticulon 2 (RTN2, SPG12) $)^{146}$ and all four proteins contribute to the shaping of tubular ER network by inducing a membrane curvature ${ }^{145-148}$. Atlastin 1 also mediates homotypic fusion of ER tubules $^{149,150}$, and ATL1 mutations were shown to alter vesicle trafficking between ER and Golgi apparatus as well as Golgi morphogenesis ${ }^{49,}{ }^{148}$. Spatacsin (SPG11) and spastizin (ZFYVE26, SPG15) interact together and co-localize with protein-trafficking vesicles, endoplasmic reticulum and microtubules ${ }^{151}$. They also interact with AP5Z1 (SPG48), one of the subunit forming the adaptor protein (AP) 5 complex $^{152}$. AP4B1 (SPG47), AP4M1 (SPG50), AP4E1 (SPG51) and AP4S1 (SPG52) form the AP4 complex ${ }^{93}$. AP complexes mediate the sorting of membrane proteins in the secretory and endocytic pathways ${ }^{152}$.

SPG7 encodes paraplegin, a protein that forms together with AFG3L2 (SPAX5) the mAAA complex present at the inner mitochondrial membrane ${ }^{153}$. mAAA is a protease essential for mitochondrial biogenesis and function, which contributes in particular to the processing of regulatory proteins and quality control surveillance ${ }^{154}$. In agreement with paraplegin function, mitochondrial abnormalities, including complex I deficiency and increased sensitivity to oxidative stress are detectable in SPG7 patients' cells ${ }^{22,153}$. Interestingly, REEP1 also partially localizes to the mitochondria or at the mitochondrial surface ${ }^{53}$, and patients with REEP1 mutations also show mitochondrial dysfunction ${ }^{52}$. Strikingly, although spastin and paraplegin have different function and localization, the consequences of the loss of function 
of the two proteins appear similar in mouse models, and mainly consist in the accumulation of organelles and neurofilaments in synaptic terminals and distal regions of axons, suggestive of an impairment of anterograde axonal transport, and leading to the apparition of axonal swellings ${ }^{155,156}$.

Finally, increasing evidence suggests that lipid metabolism is an important issue in HSP physiopathology. In addition of their role in metabolism and energy storage, lipids play a crucial role in membrane composition. The composition of the membranes in lipids and sterols controls membrane fluidity as well as compartmentalization into specialized membrane microdomains. Unsurprisingly, lipid metabolism and membrane lipid structural composition are therefore linked to several cellular functions, including intracellular membrane trafficking among many others ${ }^{157}$. Several genes mutated in HSP enter in the category of lipid metabolism, such as CYP7B1 (SPG5), CYP2U1 (SPG49/56), DDHD1 (SPG28) and DDHD2 (SPG54), GBA2 (SPG46), PNPLA6 (SPG44), FA2H (SPG35), and B4GALNT1 (SPG26). However, the precise mechanism by which alteration of these genes leads to HSP still remains unclear. Altogether, these data suggest that HSP would in many cases results from disturbance in intracellular membrane trafficking or organelle transport, either related to defects in cytoskeletal dynamics, membrane properties or composition, organelle structure and/or the connection between cytoskeleton and organelles.

HSP due to abnormalities of development or myelination (e.g. SPG1/L1CAM, SPG2/PLP1, SPG42/GJC2 or SPG67/PGAP1) are usually complex forms since these processes also affect many other neurons than the upper motor neurons.

\section{Treatment of HSP and future therapeutic perspectives}

To date, no causal therapy of an underlying genetic defect in HSP is available. The treatment remains therefore exclusively symptomatic and focuses on the main symptoms. The common strategy for treating spasticity and cerebellar ataxia is regular physiotherapy. In complex HSP subtypes, speech and occupational therapy might also be useful. The spasticity also benefits from oral medication like baclofen, tolperisone or tizanidine. Intramuscular injections of botulinum toxin $\mathrm{A}$ is then a therapeutic option to reduce the increased muscle tone ${ }^{158,159}$ although this treatment is considered as an off label procedure for the LL in most countries. Intrathecal baclofen therapy (ITB) can also alleviate spasticity in HSP. Most HSP patients are still able to work even after long disease duration. Therefore ITB therapy in HSP has the special requirement of reducing spasticity but preserving gait function ${ }^{160,161}$. ITB can be 
administered via a surgically implanted programmable pump. HSP patients that undergo an intrathecal baclofen pump implantation have to be carefully selected by applying one or several preoperative ITB testing dosis ${ }^{160,161}$. For the rare HSP patients with significant weakness in the LL the proposed symptomatic treatment of spasticity offers much less functional improvement. In HSP patients with a young onset in early childhood or adolescence orthopedic options such as special shoes for pes cavus, or achille tenotomy for equinovarus are also proposed to allow a longer autonomous gait. Anticholinergic drugs like oxybutinine chlorhydrate or trospium chlorure are used for the recurrent symptom of a detrusor overactivity and detrusor sphincter dyssynergia as expression of a central neurogenic bladder $^{19,20}$. Parkinsonism, dementia, and epilepsy are treated according to their respective guidelines. A hydrocephalus in X-chromosomal SPG1 patients shunt implantations is often performed.

In HSP patients with an identified mutation the socio-medical assistance in terms of familial counseling, especially for the risk of transmission and questions dealing with prenatal and presymptomatic testing, is also an important issue for the attending neurologist and/or geneticist.

\section{Conclusion}

The recent discoveries of new pathophysiological pathways like genes involved in fatty-acid (SPG28, SPG49, SPG54) ${ }^{87,94}$ or steroid metabolism (e.g. SPG5, SPG18) $)^{79-81,162,163}$ may open new treatment strategies and useful distinguishing biomarker for diagnostic and disease progression purposes in HSP. It also underlines the importance of clinical and genetic studies in HSP. In SPG5 HSP, a reduction of the 27-hydroxycholesterol levels might be achieved by statin therapy. Indeed, the observation of moderate decreases of plasmatic 27hydroxycholesterol after simvastatin intake in a SPG5 patient are encouraging results ${ }^{164}$, and further clinical studies are currently under way. It remains however unclear whether a reduction in the 27-hydroxycholesterol levels in the serum and/or CSF will correlate with a clinical improvement. Particularly in slowly progressive forms like SPG5, the measurement of the clinical outcome after a metabolic treatment will be difficult to undertake. Finally, the identification of environmental and/or genetic modifiers constitutes an important challenge in HSP in order to understand the huge phenotypic variability of these disorders, predict the evolution and outcome and ultimately develop new therapeutic strategies.

\section{Acknowledgements}


The authors thank Christelle Tesson for providing updated lists of HSP genes and loci. The work of the authors on HSP have been funded by ANR, the European union, the E-Rare program, and the program Investissements d'avenir” ANR-10-IAIHU-06 (IHU-A-ICM).

\section{References}

1. Novarino G, Fenstermaker AG, Zaki MS, et al. Exome sequencing links corticospinal motor neuron disease to common neurodegenerative disorders. Science (New York, NY) 2014;343:506-511.

2. Ruano L, Melo C, Silva MC, Coutinho P. The global epidemiology of hereditary ataxia and spastic paraplegia: a systematic review of prevalence studies. Neuroepidemiology 2014;42:174-183.

3. Woods CG, Cox J, Springell K, et al. Quantification of homozygosity in consanguineous individuals with autosomal recessive disease. American journal of human genetics 2006;78:889-896.

4. Schule R, Holland-Letz T, Klimpe S, et al. The Spastic Paraplegia Rating Scale (SPRS): a reliable and valid measure of disease severity. Neurology 2006;67:430-434.

5. Salinas S, Proukakis C, Crosby A, Warner TT. Hereditary spastic paraplegia: clinical features and pathogenetic mechanisms. The Lancet Neurology 2008;7:1127-1138.

6. Harding AE. Classification of the hereditary ataxias and paraplegias. Lancet 1983;1:1151-1155.

7. Pensato V, Castellotti B, Gellera C, et al. Overlapping phenotypes in complex spastic paraplegias SPG11, SPG15, SPG35 and SPG48. Brain : a journal of neurology 2014;137:1907-1920.

8. Orlacchio A, Babalini C, Borreca A, et al. SPATACSIN mutations cause autosomal recessive juvenile amyotrophic lateral sclerosis. Brain : a journal of neurology 2010;133:591-598.

9. Yang Y, Hentati A, Deng HX, et al. The gene encoding alsin, a protein with three guanine-nucleotide exchange factor domains, is mutated in a form of recessive amyotrophic lateral sclerosis. Nature genetics 2001;29:160-165.

10. Timmerman V, Clowes VE, Reid E. Overlapping molecular pathological themes link Charcot-MarieTooth neuropathies and hereditary spastic paraplegias. Exp Neurol 2013;246:14-25.

11. Kjellin K. Familial spastic paraplegia with amyotrophy, oligophrenia, and central retinal degeneration. Archives of neurology 1959;1:133-140.

12. Synofzik M, Gonzalez MA, Lourenco CM, et al. PNPLA6 mutations cause Boucher-Neuhauser and Gordon Holmes syndromes as part of a broad neurodegenerative spectrum. Brain : a journal of neurology 2014;137:69-77.

13. Puech B, Lacour A, Stevanin G, et al. Kjellin syndrome: long-term neuro-ophthalmologic follow-up and novel mutations in the SPG11 gene. Ophthalmology 2011;118:564-573.

14. Schulte T, Miterski B, Bornke C, Przuntek H, Epplen JT, Schols L. Neurophysiological findings in SPG4 patients differ from other types of spastic paraplegia. Neurology 2003;60:1529-1532.

15. Karle KN, Schule R, Klebe S, et al. Electrophysiological characterisation of motor and sensory tracts in patients with hereditary spastic paraplegia (HSP). Orphanet journal of rare diseases 2013;8:158.

16. Manganelli F, Pisciotta C, Dubbioso R, et al. Electrophysiological characterisation in hereditary spastic paraplegia type 5. Clinical neurophysiology : official journal of the International Federation of Clinical Neurophysiology 2011;122:819-822.

17. Sartucci F, Tovani S, Murri L, Sagliocco L. Motor and somatosensory evoked potentials in Autosomal Dominant Hereditary Spastic Paraparesis (ADHSP) linked to chromosome 2p, SPG4. Brain research bulletin 2007;74:243-249.

18. Lang N, Optenhoefel T, Deuschl G, Klebe S. Axonal integrity of corticospinal projections to the upper limbs in patients with pure hereditary spastic paraplegia. Clinical neurophysiology : official journal of the International Federation of Clinical Neurophysiology 2011;122:1417-1420.

19. Braschinsky M, Zopp I, Kals M, Haldre S, Gross-Paju K. Bladder dysfunction in hereditary spastic paraplegia: what to expect? Journal of neurology, neurosurgery, and psychiatry 2010;81:263-266.

20. Fourtassi M, Jacquin-Courtois S, Scheiber-Nogueira MC, et al. Bladder dysfunction in hereditary spastic paraplegia: a clinical and urodynamic evaluation. Spinal cord 2012;50:558-562.

21. Stefano G, Hawes C, Brandizzi F. ER - the key to the highway. Current opinion in plant biology 2014;22c:30-38.

22. Casari G, De Fusco M, Ciarmatori S, et al. Spastic paraplegia and OXPHOS impairment caused by mutations in paraplegin, a nuclear-encoded mitochondrial metalloprotease. Cell 1998;93:973-983. 
23. Boukhris A, Stevanin G, Feki I, et al. Tunisian hereditary spastic paraplegias: clinical variability supported by genetic heterogeneity. Clinical genetics 2009;75:527-536.

24. Franca MC, Jr., D'Abreu A, Maurer-Morelli CV, et al. Prospective neuroimaging study in hereditary spastic paraplegia with thin corpus callosum. Movement disorders : official journal of the Movement Disorder Society 2007;22:1556-1562.

25. Khan TN, Klar J, Tariq M, et al. Evidence for autosomal recessive inheritance in SPG3A caused by homozygosity for a novel ATL1 missense mutation. European journal of human genetics : EJHG 2014;22:1180-1184.

26. Esteves T, Durr A, Mundwiller E, et al. Loss of association of REEP2 with membranes leads to hereditary spastic paraplegia. American journal of human genetics 2014;94:268-277.

27. Lee JR, Srour M, Kim D, et al. De novo Mutations in the Motor Domain of KIF1A Cause Cognitive Impairment, Spastic Paraparesis, Axonal Neuropathy and Cerebellar Atrophy. Human mutation 2014.

28. Okamoto N, Miya F, Tsunoda T, et al. KIF1A mutation in a patient with progressive neurodegeneration. Journal of human genetics 2014.

29. Verny C, Guegen N, Desquiret V, et al. Hereditary spastic paraplegia-like disorder due to a mitochondrial ATP6 gene point mutation. Mitochondrion 2011;11:70-75.

30. Corona P, Lamantea E, Greco M, et al. Novel heteroplasmic mtDNA mutation in a family with heterogeneous clinical presentations. Annals of neurology 2002;51:118-122.

31. Depienne C, Fedirko E, Forlani S, et al. Exon deletions of SPG4 are a frequent cause of hereditary spastic paraplegia. Journal of medical genetics 2007;44:281-284.

32. Fonknechten N, Mavel D, Byrne P, et al. Spectrum of SPG4 mutations in autosomal dominant spastic paraplegia. Human molecular genetics 2000;9:637-644.

33. Hazan J, Fonknechten N, Mavel D, et al. Spastin, a new AAA protein, is altered in the most frequent form of autosomal dominant spastic paraplegia. Nature genetics 1999;23:296-303.

34. Depienne C, Stevanin G, Brice A, Durr A. Hereditary spastic paraplegias: an update. Current opinion in neurology 2007;20:674-680.

35. Lo Giudice T, Lombardi F, Santorelli FM, Kawarai T, Orlacchio A. Hereditary spastic paraplegia: Clinical-genetic characteristics and evolving molecular mechanisms. Experimental neurology 2014;261C:518-539.

36. Rainier S, Hedera P, Alvarado D, et al. Hereditary spastic paraplegia linked to chromosome 14q11q21: reduction of the SPG3 locus interval from 5.3 to $2.7 \mathrm{cM}$. Journal of medical genetics 2001;38:E39.

37. Durr A, Camuzat A, Colin E, et al. Atlastin1 mutations are frequent in young-onset autosomal dominant spastic paraplegia. Archives of neurology 2004;61:1867-1872.

38. Namekawa M, Ribai P, Nelson I, et al. SPG3A is the most frequent cause of hereditary spastic paraplegia with onset before age 10 years. Neurology 2006;66:112-114.

39. Guelly C, Zhu PP, Leonardis L, et al. Targeted high-throughput sequencing identifies mutations in atlastin-1 as a cause of hereditary sensory neuropathy type I. American journal of human genetics 2011;88:99-105.

40. Zhao X, Alvarado D, Rainier S, et al. Mutations in a newly identified GTPase gene cause autosomal dominant hereditary spastic paraplegia. Nature genetics 2001;29:326-331.

41. Sauter SM, Engel W, Neumann LM, Kunze J, Neesen J. Novel mutations in the Atlastin gene (SPG3A) in families with autosomal dominant hereditary spastic paraplegia and evidence for late onset forms of HSP linked to the SPG3A locus. Human mutation 2004;23:98.

42. Leonardis L, Auer-Grumbach M, Papic L, Zidar J. The N355K atlastin 1 mutation is associated with hereditary sensory neuropathy and pyramidal tract features. European journal of neurology : the official journal of the European Federation of Neurological Societies 2012;19:992-998.

43. Smith BN, Bevan S, Vance C, et al. Four novel SPG3A/atlastin mutations identified in autosomal dominant hereditary spastic paraplegia kindreds with intra-familial variability in age of onset and complex phenotype. Clinical genetics 2009;75:485-489.

44. Fusco C, Frattini D, Farnetti E, Nicoli D, Casali B, Della Giustina E. Very early onset and severe complicated phenotype caused by a new spastic paraplegia 3A gene mutation. Journal of child neurology 2012;27:1348-1350.

45. Fusco C, Frattini D, Farnetti E, et al. Hereditary spastic paraplegia and axonal motor neuropathy caused by a novel SPG3A de novo mutation. Brain \& development 2010;32:592-594. 
46. Rainier S, Sher C, Reish O, Thomas D, Fink JK. De novo occurrence of novel SPG3A/atlastin mutation presenting as cerebral palsy. Archives of neurology 2006;63:445-447.

47. Scarano V, Mancini P, Criscuolo C, et al. The R495W mutation in SPG3A causes spastic paraplegia associated with axonal neuropathy. Journal of neurology 2005;252:901-903.

48. Muriel MP, Dauphin A, Namekawa M, Gervais A, Brice A, Ruberg M. Atlastin-1, the dynamin-like GTPase responsible for spastic paraplegia SPG3A, remodels lipid membranes and may form tubules and vesicles in the endoplasmic reticulum. Journal of neurochemistry 2009;110:1607-1616.

49. Namekawa M, Muriel MP, Janer A, et al. Mutations in the SPG3A gene encoding the GTPase atlastin interfere with vesicle trafficking in the ER/Golgi interface and Golgi morphogenesis. Molecular and cellular neurosciences 2007;35:1-13.

50. Beetz C, Schule R, Deconinck T, et al. REEP1 mutation spectrum and genotype/phenotype correlation in hereditary spastic paraplegia type 31. Brain : a journal of neurology 2008;131:1078-1086.

51. Erichsen AK, Koht J, Stray-Pedersen A, Abdelnoor M, Tallaksen CM. Prevalence of hereditary ataxia and spastic paraplegia in southeast Norway: a population-based study. Brain : a journal of neurology 2009;132:1577-1588.

52. Goizet C, Depienne C, Benard G, et al. REEP1 mutations in SPG31: frequency, mutational spectrum, and potential association with mitochondrial morpho-functional dysfunction. Human mutation 2011;32:1118-1127.

53. Zuchner S, Wang G, Tran-Viet KN, et al. Mutations in the novel mitochondrial protein REEP1 cause hereditary spastic paraplegia type 31. American journal of human genetics 2006;79:365-369.

54. Hewamadduma C, McDermott C, Kirby J, et al. New pedigrees and novel mutation expand the phenotype of REEP1-associated hereditary spastic paraplegia (HSP). Neurogenetics 2009;10:105-110.

55. Reid E, Kloos M, Ashley-Koch A, et al. A kinesin heavy chain (KIF5A) mutation in hereditary spastic paraplegia (SPG10). American journal of human genetics 2002;71:1189-1194.

56. Crimella C, Baschirotto C, Arnoldi A, et al. Mutations in the motor and stalk domains of KIF5A in spastic paraplegia type 10 and in axonal Charcot-Marie-Tooth type 2. Clinical genetics 2012;82:157164.

57. Goizet C, Boukhris A, Mundwiller E, et al. Complicated forms of autosomal dominant hereditary spastic paraplegia are frequent in SPG10. Human mutation 2009;30:E376-385.

58. Schule R, Kremer BP, Kassubek J, et al. SPG10 is a rare cause of spastic paraplegia in European families. Journal of neurology, neurosurgery, and psychiatry 2008;79:584-587.

59. Blair MA, Ma S, Hedera P. Mutation in KIF5A can also cause adult-onset hereditary spastic paraplegia. Neurogenetics 2006;7:47-50.

60. Reid E, Dearlove AM, Rhodes M, Rubinsztein DC. A new locus for autosomal dominant "pure" hereditary spastic paraplegia mapping to chromosome 12q13, and evidence for further genetic heterogeneity. American journal of human genetics 1999;65:757-763.

61. Liu YT, Laura M, Hersheson J, et al. Extended phenotypic spectrum of KIF5A mutations: From spastic paraplegia to axonal neuropathy. Neurology 2014;83:612-619.

62. Collongues N, Depienne C, Boehm N, et al. Novel SPG10 mutation associated with dysautonomia, spinal cord atrophy, and skin biopsy abnormality. European journal of neurology : the official journal of the European Federation of Neurological Societies 2013;20:398-401.

63. Ebbing B, Mann K, Starosta A, et al. Effect of spastic paraplegia mutations in KIF5A kinesin on transport activity. Human molecular genetics 2008;17:1245-1252.

64. Rainier S, Chai JH, Tokarz D, Nicholls RD, Fink JK. NIPA1 gene mutations cause autosomal dominant hereditary spastic paraplegia (SPG6). American journal of human genetics 2003;73:967971.

65. Klebe S, Lacour A, Durr A, et al. NIPA1 (SPG6) mutations are a rare cause of autosomal dominant spastic paraplegia in Europe. Neurogenetics 2007;8:155-157.

66. Kaneko S, Kawarai T, Yip E, et al. Novel SPG6 mutation p.A100T in a Japanese family with autosomal dominant form of hereditary spastic paraplegia. Movement disorders : official journal of the Movement Disorder Society 2006;21:1531-1533.

67. Munhoz RP, Kawarai T, Teive HA, et al. Clinical and genetic study of a Brazilian family with spastic paraplegia (SPG6 locus). Movement disorders : official journal of the Movement Disorder Society 2006;21:279-281.

68. Du J, Hu YC, Tang BS, et al. Expansion of the phenotypic spectrum of SPG6 caused by mutation in NIPA1. Clinical neurology and neurosurgery 2011;113:480-482. 
69. Reed JA, Wilkinson PA, Patel H, et al. A novel NIPA1 mutation associated with a pure form of autosomal dominant hereditary spastic paraplegia. Neurogenetics 2005;6:79-84.

70. Cooper GM, Coe BP, Girirajan S, et al. A copy number variation morbidity map of developmental delay. Nature genetics 2011;43:838-846.

71. Elleuch N, Depienne C, Benomar A, et al. Mutation analysis of the paraplegin gene (SPG7) in patients with hereditary spastic paraplegia. Neurology 2006;66:654-659.

72. van Gassen KL, van der Heijden CD, de Bot ST, et al. Genotype-phenotype correlations in spastic paraplegia type 7: a study in a large Dutch cohort. Brain : a journal of neurology 2012;135:2994-3004.

73. Klebe S, Depienne C, Gerber S, et al. Spastic paraplegia gene 7 in patients with spasticity and/or optic neuropathy. Brain : a journal of neurology 2012;135:2980-2993.

74. Bonn F, Pantakani K, Shoukier M, Langer T, Mannan AU. Functional evaluation of paraplegin mutations by a yeast complementation assay. Human mutation 2010;31:617-621.

75. Tzoulis C, Denora PS, Santorelli FM, Bindoff LA. Hereditary spastic paraplegia caused by the novel mutation 1047insC in the SPG7 gene. Journal of neurology 2008;255:1142-1144.

76. Brugman F, Scheffer H, Wokke JH, et al. Paraplegin mutations in sporadic adult-onset upper motor neuron syndromes. Neurology 2008;71:1500-1505.

77. McDermott CJ, Dayaratne RK, Tomkins J, et al. Paraplegin gene analysis in hereditary spastic paraparesis (HSP) pedigrees in northeast England. Neurology 2001;56:467-471.

78. De Michele G, De Fusco M, Cavalcanti F, et al. A new locus for autosomal recessive hereditary spastic paraplegia maps to chromosome 16q24.3. American journal of human genetics 1998;63:135139.

79. Goizet C, Boukhris A, Durr A, et al. CYP7B1 mutations in pure and complex forms of hereditary spastic paraplegia type 5. Brain : a journal of neurology 2009;132:1589-1600.

80. Arnoldi A, Crimella C, Tenderini E, et al. Clinical phenotype variability in patients with hereditary spastic paraplegia type 5 associated with CYP7B1 mutations. Clinical genetics 2012;81:150-157.

81. Schule R, Brandt E, Karle KN, et al. Analysis of CYP7B1 in non-consanguineous cases of hereditary spastic paraplegia. Neurogenetics 2009;10:97-104.

82. Biancheri R, Ciccolella M, Rossi A, et al. White matter lesions in spastic paraplegia with mutations in SPG5/CYP7B1. Neuromuscular disorders : NMD 2009;19:62-65.

83. Schule R, Siddique T, Deng HX, et al. Marked accumulation of 27-hydroxycholesterol in SPG5 patients with hereditary spastic paresis. Journal of lipid research 2010;51:819-823.

84. Erlich Y, Edvardson S, Hodges E, et al. Exome sequencing and disease-network analysis of a single family implicate a mutation in KIF1A in hereditary spastic paraparesis. Genome research 2011;21:658-664.

85. Klebe S, Lossos A, Azzedine H, et al. KIF1A missense mutations in SPG30, an autosomal recessive spastic paraplegia: distinct phenotypes according to the nature of the mutations. European journal of human genetics : EJHG 2012;20:645-649.

86. Hamdan FF, Gauthier J, Araki Y, et al. Excess of de novo deleterious mutations in genes associated with glutamatergic systems in nonsyndromic intellectual disability. American journal of human genetics 2011;88:306-316.

87. Tesson C, Nawara M, Salih MA, et al. Alteration of fatty-acid-metabolizing enzymes affects mitochondrial form and function in hereditary spastic paraplegia. American journal of human genetics 2012;91:1051-1064.

88. Stevanin G, Azzedine H, Denora P, et al. Mutations in SPG11 are frequent in autosomal recessive spastic paraplegia with thin corpus callosum, cognitive decline and lower motor neuron degeneration. Brain : a journal of neurology 2008;131:772-784.

89. Goizet C, Boukhris A, Maltete D, et al. SPG15 is the second most common cause of hereditary spastic paraplegia with thin corpus callosum. Neurology 2009;73:1111-1119.

90. Martin E, Schule R, Smets K, et al. Loss of function of glucocerebrosidase GBA2 is responsible for motor neuron defects in hereditary spastic paraplegia. American journal of human genetics 2013;92:238-244.

91. Simpson MA, Cross H, Proukakis C, et al. Maspardin is mutated in mast syndrome, a complicated form of hereditary spastic paraplegia associated with dementia. American journal of human genetics 2003;73:1147-1156.

92. Orthmann-Murphy JL, Salsano E, Abrams CK, et al. Hereditary spastic paraplegia is a novel phenotype for GJA12/GJC2 mutations. Brain : a journal of neurology 2009;132:426-438. 
93. Abou Jamra R, Philippe O, Raas-Rothschild A, et al. Adaptor protein complex 4 deficiency causes severe autosomal-recessive intellectual disability, progressive spastic paraplegia, shy character, and short stature. American journal of human genetics 2011;88:788-795.

94. Schuurs-Hoeijmakers JH, Geraghty MT, Kamsteeg EJ, et al. Mutations in DDHD2, encoding an intracellular phospholipase A(1), cause a recessive form of complex hereditary spastic paraplegia. American journal of human genetics 2012;91:1073-1081.

95. Schrander-Stumpel C, Howeler C, Jones M, et al. Spectrum of X-linked hydrocephalus (HSAS), MASA syndrome, and complicated spastic paraplegia (SPG1): Clinical review with six additional families. American journal of medical genetics 1995;57:107-116.

96. Dick KJ, Eckhardt M, Paisan-Ruiz C, et al. Mutation of FA2H underlies a complicated form of hereditary spastic paraplegia (SPG35). Human mutation 2010;31:E1251-1260.

97. Stevanin G, Santorelli FM, Azzedine H, et al. Mutations in SPG11, encoding spatacsin, are a major cause of spastic paraplegia with thin corpus callosum. Nature genetics 2007;39:366-372.

98. Boukhris A, Stevanin G, Feki I, et al. Hereditary spastic paraplegia with mental impairment and thin corpus callosum in Tunisia: SPG11, SPG15, and further genetic heterogeneity. Archives of neurology 2008;65:393-402.

99. Schule R, Schlipf N, Synofzik M, et al. Frequency and phenotype of SPG11 and SPG15 in complicated hereditary spastic paraplegia. Journal of neurology, neurosurgery, and psychiatry 2009;80:1402-1404.

100. Giannoccaro MP, Liguori R, Arnoldi A, Donadio V, Avoni P, Bassi MT. Atypical late-onset hereditary spastic paraplegia with thin corpus callosum due to novel compound heterozygous mutations in the SPG11 gene. Journal of neurology 2014;261:1825-1827.

101. Guidubaldi A, Piano C, Santorelli FM, et al. Novel mutations in SPG11 cause hereditary spastic paraplegia associated with early-onset levodopa-responsive Parkinsonism. Movement disorders : official journal of the Movement Disorder Society 2011;26:553-556.

102. Daoud H, Zhou S, Noreau A, et al. Exome sequencing reveals SPG11 mutations causing juvenile ALS. Neurobiology of aging 2012;33:839 e835-839.

103. Webb S, Patterson V, Hutchinson M. Two families with autosomal recessive spastic paraplegia, pigmented maculopathy, and dementia. Journal of neurology, neurosurgery, and psychiatry 1997;63:628-632.

104. Denora PS, Muglia M, Casali C, et al. Spastic paraplegia with thinning of the corpus callosum and white matter abnormalities: further mutations and relative frequency in ZFYVE26/SPG15 in the Italian population. Journal of the neurological sciences 2009;277:22-25.

105. Rowland LP. Primary lateral sclerosis, hereditary spastic paraplegia, and mutations in the alsin gene: historical background for the first International Conference. Amyotrophic lateral sclerosis and other motor neuron disorders : official publication of the World Federation of Neurology, Research Group on Motor Neuron Diseases 2005;6:67-76.

106. Eymard-Pierre E, Lesca G, Dollet S, et al. Infantile-onset ascending hereditary spastic paralysis is associated with mutations in the alsin gene. American journal of human genetics 2002;71:518-527.

107. De Jonghe P, Auer-Grumbach M, Irobi J, et al. Autosomal dominant juvenile amyotrophic lateral sclerosis and distal hereditary motor neuronopathy with pyramidal tract signs: synonyms for the same disorder? Brain : a journal of neurology 2002;125:1320-1325.

108. Chen YZ, Bennett CL, Huynh HM, et al. DNA/RNA helicase gene mutations in a form of juvenile amyotrophic lateral sclerosis (ALS4). American journal of human genetics 2004;74:1128-1135.

109. Magre J, Delepine M, Khallouf E, et al. Identification of the gene altered in Berardinelli-Seip congenital lipodystrophy on chromosome 11q13. Nature genetics 2001;28:365-370.

110. Windpassinger C, Auer-Grumbach M, Irobi J, et al. Heterozygous missense mutations in BSCL2 are associated with distal hereditary motor neuropathy and Silver syndrome. Nature genetics 2004;36:271276.

111. Irobi J, Van den Bergh P, Merlini L, et al. The phenotype of motor neuropathies associated with BSCL2 mutations is broader than Silver syndrome and distal HMN type V. Brain : a journal of neurology 2004;127:2124-2130.

112. Klebe S, Azzedine H, Durr A, et al. Autosomal recessive spastic paraplegia (SPG30) with mild ataxia and sensory neuropathy maps to chromosome 2q37.3. Brain : a journal of neurology 2006;129:14561462. 
113. Riviere JB, Ramalingam S, Lavastre V, et al. KIF1A, an axonal transporter of synaptic vesicles, is mutated in hereditary sensory and autonomic neuropathy type 2 . American journal of human genetics 2011;89:219-230.

114. Beetz C, Pieber TR, Hertel N, et al. Exome sequencing identifies a REEP1 mutation involved in distal hereditary motor neuropathy type V. American journal of human genetics 2012;91:139-145.

115. Blauw HM, van Rheenen W, Koppers M, et al. NIPA1 polyalanine repeat expansions are associated with amyotrophic lateral sclerosis. Human molecular genetics 2012;21:2497-2502.

116. Ito D, Suzuki N. Molecular pathogenesis of seipin/BSCL2-related motor neuron diseases. Annals of neurology 2007;61:237-250.

117. Guillen-Navarro E, Sanchez-Iglesias S, Domingo-Jimenez R, et al. A new seipin-associated neurodegenerative syndrome. Journal of medical genetics 2013;50:401-409.

118. Silver JR. Familial spastic paraplegia with amyotrophy of the hands. Annals of human genetics 1966;30:69-75.

119. Auer-Grumbach M, Loscher WN, Wagner K, et al. Phenotypic and genotypic heterogeneity in hereditary motor neuronopathy type V: a clinical, electrophysiological and genetic study. Brain : a journal of neurology 2000;123 ( Pt 8):1612-1623.

120. Auer-Grumbach M, Schlotter-Weigel B, Lochmuller H, et al. Phenotypes of the N88S BerardinelliSeip congenital lipodystrophy 2 mutation. Annals of neurology 2005;57:415-424.

121. van de Warrenburg BP, Scheffer H, van Eijk JJ, et al. BSCL2 mutations in two Dutch families with overlapping Silver syndrome-distal hereditary motor neuropathy. Neuromuscular disorders : NMD 2006;16:122-125.

122. Dierick I, Baets J, Irobi J, et al. Relative contribution of mutations in genes for autosomal dominant distal hereditary motor neuropathies: a genotype-phenotype correlation study. Brain : a journal of neurology 2008;131:1217-1227.

123. Windpassinger C, Wagner K, Petek E, Fischer R, Auer-Grumbach M. Refinement of the Silver syndrome locus on chromosome 11q12-q14 in four families and exclusion of eight candidate genes. Human genetics 2003;114:99-109.

124. Hammer MB, Eleuch-Fayache G, Schottlaender LV, et al. Mutations in GBA2 cause autosomalrecessive cerebellar ataxia with spasticity. American journal of human genetics 2013;92:245-251.

125. Dor T, Cinnamon Y, Raymond L, et al. KIF1C mutations in two families with hereditary spastic paraparesis and cerebellar dysfunction. Journal of medical genetics 2014;51:137-142.

126. Anheim M, Chaigne D, Fleury M, et al. [Autosomal recessive spastic ataxia of Charlevoix-Saguenay: study of a family and review of the literature]. Revue neurologique 2008;164:363-368.

127. Engert JC, Berube P, Mercier J, et al. ARSACS, a spastic ataxia common in northeastern Quebec, is caused by mutations in a new gene encoding an 11.5-kb ORF. Nature genetics 2000;24:120-125.

128. Anheim M, Tranchant C, Koenig M. The autosomal recessive cerebellar ataxias. N Engl J Med 2012;366:636-646.

129. Schulz JB, Boesch S, Burk K, et al. Diagnosis and treatment of Friedreich ataxia: a European perspective. Nat Rev Neurol 2009;5:222-234.

130. Bayat V, Thiffault I, Jaiswal M, et al. Mutations in the mitochondrial methionyl-tRNA synthetase cause a neurodegenerative phenotype in flies and a recessive ataxia (ARSAL) in humans. PLoS biology 2012;10:e1001288.

131. Di Bella D, Lazzaro F, Brusco A, et al. Mutations in the mitochondrial protease gene AFG3L2 cause dominant hereditary ataxia SCA28. Nature genetics 2010;42:313-321.

132. Bouslam N, Bouhouche A, Benomar A, et al. A novel locus for autosomal recessive spastic ataxia on chromosome 17p. Human genetics 2007;121:413-420.

133. Winner B, Uyanik G, Gross C, et al. Clinical progression and genetic analysis in hereditary spastic paraplegia with thin corpus callosum in spastic gait gene 11 (SPG11). Archives of neurology 2004;61:117-121.

134. Orlen H, Melberg A, Raininko R, et al. SPG11 mutations cause Kjellin syndrome, a hereditary spastic paraplegia with thin corpus callosum and central retinal degeneration. American journal of medical genetics Part B, Neuropsychiatric genetics : the official publication of the International Society of Psychiatric Genetics 2009;150B:984-992.

135. Lossos A, Teltsh O, Milman T, et al. Severe methylenetetrahydrofolate reductase deficiency: clinical clues to a potentially treatable cause of adult-onset hereditary spastic paraplegia. JAMA neurology 2014;71:901-904. 
136. Vandewalle J, Van Esch H, Govaerts K, et al. Dosage-dependent severity of the phenotype in patients with mental retardation due to a recurrent copy-number gain at Xq28 mediated by an unusual recombination. American journal of human genetics 2009;85:809-822.

137. Dufke C, Schlipf N, Schule R, et al. A high-throughput resequencing microarray for autosomal dominant spastic paraplegia genes. Neurogenetics 2012;13:215-227.

138. Kumar KR, Blair NF, Vandebona H, et al. Targeted next generation sequencing in SPAST-negative hereditary spastic paraplegia. Journal of neurology 2013;260:2516-2522.

139. Blackstone C. Cellular pathways of hereditary spastic paraplegia. Annu Rev Neurosci 2012;35:25-47.

140. Caballero Oteyza A, Battaloglu E, Ocek L, et al. Motor protein mutations cause a new form of hereditary spastic paraplegia. Neurology 2014;82:2007-2016.

141. Errico A, Ballabio A, Rugarli EI. Spastin, the protein mutated in autosomal dominant hereditary spastic paraplegia, is involved in microtubule dynamics. Human molecular genetics 2002;11:153-163.

142. McDermott CJ, Grierson AJ, Wood JD, et al. Hereditary spastic paraparesis: disrupted intracellular transport associated with spastin mutation. Annals of neurology 2003;54:748-759.

143. Sanderson CM, Connell JW, Edwards TL, et al. Spastin and atlastin, two proteins mutated in autosomal-dominant hereditary spastic paraplegia, are binding partners. Human molecular genetics 2006;15:307-318.

144. Evans K, Keller C, Pavur K, Glasgow K, Conn B, Lauring B. Interaction of two hereditary spastic paraplegia gene products, spastin and atlastin, suggests a common pathway for axonal maintenance. Proceedings of the National Academy of Sciences of the United States of America 2006;103:1066610671.

145. Park SH, Zhu PP, Parker RL, Blackstone C. Hereditary spastic paraplegia proteins REEP1, spastin, and atlastin-1 coordinate microtubule interactions with the tubular ER network. The Journal of clinical investigation 2010;120:1097-1110.

146. Montenegro G, Rebelo AP, Connell J, et al. Mutations in the ER-shaping protein reticulon 2 cause the axon-degenerative disorder hereditary spastic paraplegia type 12 . The Journal of clinical investigation 2012;122:538-544.

147. Hu J, Shibata Y, Zhu PP, et al. A class of dynamin-like GTPases involved in the generation of the tubular ER network. Cell 2009;138:549-561.

148. Rismanchi N, Soderblom C, Stadler J, Zhu PP, Blackstone C. Atlastin GTPases are required for Golgi apparatus and ER morphogenesis. Human molecular genetics 2008;17:1591-1604.

149. Orso G, Pendin D, Liu S, et al. Homotypic fusion of ER membranes requires the dynamin-like GTPase atlastin. Nature 2009;460:978-983.

150. Bian X, Klemm RW, Liu TY, et al. Structures of the atlastin GTPase provide insight into homotypic fusion of endoplasmic reticulum membranes. Proceedings of the National Academy of Sciences of the United States of America 2011;108:3976-3981.

151. Murmu RP, Martin E, Rastetter A, et al. Cellular distribution and subcellular localization of spatacsin and spastizin, two proteins involved in hereditary spastic paraplegia. Molecular and cellular neurosciences 2011;47:191-202.

152. Hirst J, Barlow LD, Francisco GC, et al. The fifth adaptor protein complex. PLoS biology 2011;9:e1001170.

153. Atorino L, Silvestri L, Koppen M, et al. Loss of m-AAA protease in mitochondria causes complex I deficiency and increased sensitivity to oxidative stress in hereditary spastic paraplegia. The Journal of cell biology 2003;163:777-787.

154. Nolden M, Ehses S, Koppen M, Bernacchia A, Rugarli EI, Langer T. The m-AAA protease defective in hereditary spastic paraplegia controls ribosome assembly in mitochondria. Cell 2005;123:277-289.

155. Ferreirinha F, Quattrini A, Pirozzi M, et al. Axonal degeneration in paraplegin-deficient mice is associated with abnormal mitochondria and impairment of axonal transport. The Journal of clinical investigation 2004;113:231-242.

156. Tarrade A, Fassier C, Courageot S, et al. A mutation of spastin is responsible for swellings and impairment of transport in a region of axon characterized by changes in microtubule composition. Human molecular genetics 2006;15:3544-3558.

157. Spector AA, Yorek MA. Membrane lipid composition and cellular function. Journal of lipid research 1985;26:1015-1035. 
158. Rousseaux M, Launay MJ, Kozlowski O, Daveluy W. Botulinum toxin injection in patients with hereditary spastic paraparesis. European journal of neurology : the official journal of the European Federation of Neurological Societies 2007;14:206-212.

159. Hecht MJ, Stolze H, Auf dem Brinke M, et al. Botulinum neurotoxin type A injections reduce spasticity in mild to moderate hereditary spastic paraplegia--report of 19 cases. Movement disorders : official journal of the Movement Disorder Society 2008;23:228-233.

160. Klebe S, Stolze H, Kopper F, et al. Objective assessment of gait after intrathecal baclofen in hereditary spastic paraplegia. Journal of neurology 2005;252:991-993.

161. Margetis K, Korfias S, Boutos N, et al. Intrathecal baclofen therapy for the symptomatic treatment of hereditary spastic paraplegia. Clinical neurology and neurosurgery 2014;123:142-145.

162. Yildirim Y, Orhan EK, Iseri SA, et al. A frameshift mutation of ERLIN2 in recessive intellectual disability, motor dysfunction and multiple joint contractures. Human molecular genetics 2011;20:1886-1892.

163. Tsaousidou MK, Ouahchi K, Warner TT, et al. Sequence alterations within CYP7B1 implicate defective cholesterol homeostasis in motor-neuron degeneration. American journal of human genetics 2008;82:510-515.

164. Mignarri A, Malandrini A, Del Puppo M, et al. Hereditary spastic paraplegia type 5: a potentially treatable disorder of cholesterol metabolism. Journal of neurology 2014;261:617-619.

165. Valdmanis PN, Meijer IA, Reynolds A, et al. Mutations in the KIAA0196 gene at the SPG8 locus cause hereditary spastic paraplegia. American journal of human genetics 2007;80:152-161.

166. Seri M, Cusano R, Forabosco P, et al. Genetic mapping to 10q23.3-q24.2, in a large Italian pedigree, of a new syndrome showing bilateral cataracts, gastroesophageal reflux, and spastic paraparesis with amyotrophy. American journal of human genetics 1999;64:586-593.

167. Hansen JJ, Durr A, Cournu-Rebeix I, et al. Hereditary spastic paraplegia SPG13 is associated with a mutation in the gene encoding the mitochondrial chaperonin Hsp60. American journal of human genetics 2002;70:1328-1332.

168. Valente EM, Brancati F, Caputo V, et al. Novel locus for autosomal dominant pure hereditary spastic paraplegia (SPG19) maps to chromosome 9q33-q34. Annals of neurology 2002;51:681-685.

169. Orlacchio A, Kawarai T, Gaudiello F, St George-Hyslop PH, Floris R, Bernardi G. New locus for hereditary spastic paraplegia maps to chromosome 1p31.1-1p21.1. Annals of neurology 2005;58:423429.

170. Mannan AU, Krawen P, Sauter SM, et al. ZFYVE27 (SPG33), a novel spastin-binding protein, is mutated in hereditary spastic paraplegia. American journal of human genetics 2006;79:351-357.

171. Schule R, Bonin M, Durr A, et al. Autosomal dominant spastic paraplegia with peripheral neuropathy maps to chr12q23-24. Neurology 2009;72:1893-1898.

172. Hanein S, Durr A, Ribai P, et al. A novel locus for autosomal dominant "uncomplicated" hereditary spastic paraplegia maps to chromosome 8p21.1-q13.3. Human genetics 2007;122:261-273.

173. Orlacchio A, Patrono C, Gaudiello F, et al. Silver syndrome variant of hereditary spastic paraplegia: A locus to 4p and allelism with SPG4. Neurology 2008;70:1959-1966.

174. Zhao GH, Hu ZM, Shen L, et al. A novel candidate locus on chromosome 11p14.1-p11.2 for autosomal dominant hereditary spastic paraplegia. Chinese medical journal 2008;121:430-434.

175. Lin P, Li J, Liu Q, et al. A missense mutation in SLC33A1, which encodes the acetyl-CoA transporter, causes autosomal-dominant spastic paraplegia (SPG42). American journal of human genetics 2008;83:752-759.

176. Vazza G, Zortea M, Boaretto F, Micaglio GF, Sartori V, Mostacciuolo ML. A new locus for autosomal recessive spastic paraplegia associated with mental retardation and distal motor neuropathy, SPG14, maps to chromosome 3q27-q28. American journal of human genetics 2000;67:504-509.

177. Hanein S, Martin E, Boukhris A, et al. Identification of the SPG15 gene, encoding spastizin, as a frequent cause of complicated autosomal-recessive spastic paraplegia, including Kjellin syndrome. American journal of human genetics 2008;82:992-1002.

178. Alazami AM, Adly N, Al Dhalaan H, Alkuraya FS. A nullimorphic ERLIN2 mutation defines a complicated hereditary spastic paraplegia locus (SPG18). Neurogenetics 2011;12:333-336.

179. Patel H, Cross H, Proukakis C, et al. SPG20 is mutated in Troyer syndrome, an hereditary spastic paraplegia. Nature genetics 2002;31:347-348.

180. Blumen SC, Bevan S, Abu-Mouch S, et al. A locus for complicated hereditary spastic paraplegia maps to chromosome 1q24-q32. Annals of neurology 2003;54:796-803. 
181. Hodgkinson CA, Bohlega S, Abu-Amero SN, et al. A novel form of autosomal recessive pure hereditary spastic paraplegia maps to chromosome 13q14. Neurology 2002;59:1905-1909.

182. Zortea M, Vettori A, Trevisan CP, et al. Genetic mapping of a susceptibility locus for disc herniation and spastic paraplegia on 6q23.3-q24.1. Journal of medical genetics 2002;39:387-390.

183. Boukhris A, Schule R, Loureiro JL, et al. Alteration of ganglioside biosynthesis responsible for complex hereditary spastic paraplegia. American journal of human genetics 2013;93:118-123.

184. Meijer IA, Cossette P, Roussel J, Benard M, Toupin S, Rouleau GA. A novel locus for pure recessive hereditary spastic paraplegia maps to 10q22.1-10q24.1. Annals of neurology 2004;56:579-582.

185. Stevanin G, Paternotte C, Coutinho P, et al. A new locus for autosomal recessive spastic paraplegia (SPG32) on chromosome 14q12-q21. Neurology 2007;68:1837-1840.

186. Rainier S, Bui M, Mark E, et al. Neuropathy target esterase gene mutations cause motor neuron disease. American journal of human genetics 2008;82:780-785.

187. Landoure G, Zhu PP, Lourenco CM, et al. Hereditary spastic paraplegia type 43 (SPG43) is caused by mutation in C19orf12. Human mutation 2013;34:1357-1360.

188. Dursun U, Koroglu C, Kocasoy Orhan E, Ugur SA, Tolun A. Autosomal recessive spastic paraplegia (SPG45) with mental retardation maps to 10q24.3-q25.1. Neurogenetics 2009;10:325-331.

189. Slabicki M, Theis M, Krastev DB, et al. A genome-scale DNA repair RNAi screen identifies SPG48 as a novel gene associated with hereditary spastic paraplegia. PLoS biology 2010;8:e1000408.

190. Oz-Levi D, Ben-Zeev B, Ruzzo EK, et al. Mutation in TECPR2 reveals a role for autophagy in hereditary spastic paraparesis. American journal of human genetics 2012;91:1065-1072.

191. Verkerk AJ, Schot R, Dumee B, et al. Mutation in the AP4M1 gene provides a model for neuroaxonal injury in cerebral palsy. American journal of human genetics 2009;85:40-52.

192. Moreno-De-Luca A, Helmers SL, Mao H, et al. Adaptor protein complex-4 (AP-4) deficiency causes a novel autosomal recessive cerebral palsy syndrome with microcephaly and intellectual disability. Journal of medical genetics 2011;48:141-144.

193. Zivony-Elboum Y, Westbroek W, Kfir N, et al. A founder mutation in Vps37A causes autosomal recessive complex hereditary spastic paraparesis. Journal of medical genetics 2012;49:462-472.

194. Shimazaki H, Takiyama Y, Ishiura H, et al. A homozygous mutation of C12orf65 causes spastic paraplegia with optic atrophy and neuropathy (SPG55). Journal of medical genetics 2012;49:777-784.

195. Ishiura H, Sako W, Yoshida M, et al. The TRK-fused gene is mutated in hereditary motor and sensory neuropathy with proximal dominant involvement. American journal of human genetics 2012;91:320329.

196. Beetz C, Johnson A, Schuh AL, et al. Inhibition of TFG function causes hereditary axon degeneration by impairing endoplasmic reticulum structure. Proceedings of the National Academy of Sciences of the United States of America 2013;110:5091-5096.

197. Shimazaki H, Honda J, Naoi T, et al. Autosomal-recessive complicated spastic paraplegia with a novel lysosomal trafficking regulator gene mutation. Journal of neurology, neurosurgery, and psychiatry 2014;85:1024-1028.

198. Bouhouche A, Benomar A, Bouslam N, Chkili T, Yahyaoui M. Mutation in the epsilon subunit of the cytosolic chaperonin-containing t-complex peptide-1 (Cct5) gene causes autosomal recessive mutilating sensory neuropathy with spastic paraplegia. Journal of medical genetics 2006;43:441-443.

199. Zanni G, Scotton C, Passarelli C, et al. Exome sequencing in a family with intellectual disability, early onset spasticity, and cerebellar atrophy detects a novel mutation in EXOSC3. Neurogenetics 2013;14:247-250.

200. Halevy A, Lerer I, Cohen R, et al. Novel EXOSC3 mutation causes complicated hereditary spastic paraplegia. Journal of neurology 2014.

201. Oates EC, Rossor AM, Hafezparast M, et al. Mutations in BICD2 cause dominant congenital spinal muscular atrophy and hereditary spastic paraplegia. American journal of human genetics 2013;92:965973.

202. Jouet M, Rosenthal A, Armstrong G, et al. X-linked spastic paraplegia (SPG1), MASA syndrome and X-linked hydrocephalus result from mutations in the L1 gene. Nature genetics 1994;7:402-407.

203. Saugier-Veber P, Munnich A, Bonneau D, et al. X-linked spastic paraplegia and Pelizaeus-Merzbacher disease are allelic disorders at the proteolipid protein locus. Nature genetics 1994;6:257-262.

204. Schwartz CE, May MM, Carpenter NJ, et al. Allan-Herndon-Dudley syndrome and the monocarboxylate transporter 8 (MCT8) gene. American journal of human genetics 2005;77:41-53. 
205. Steinmuller R, Lantigua-Cruz A, Garcia-Garcia R, Kostrzewa M, Steinberger D, Muller U. Evidence of a third locus in X-linked recessive spastic paraplegia. Human genetics 1997;100:287-289.

206. Macedo-Souza LI, Kok F, Santos S, et al. Reevaluation of a large family defines a new locus for Xlinked recessive pure spastic paraplegia (SPG34) on chromosome Xq25. Neurogenetics 2008;9:225226. 
Figure 1. Overview of the clinical and genetic overlap between HSP and other neurodegenerative disorders

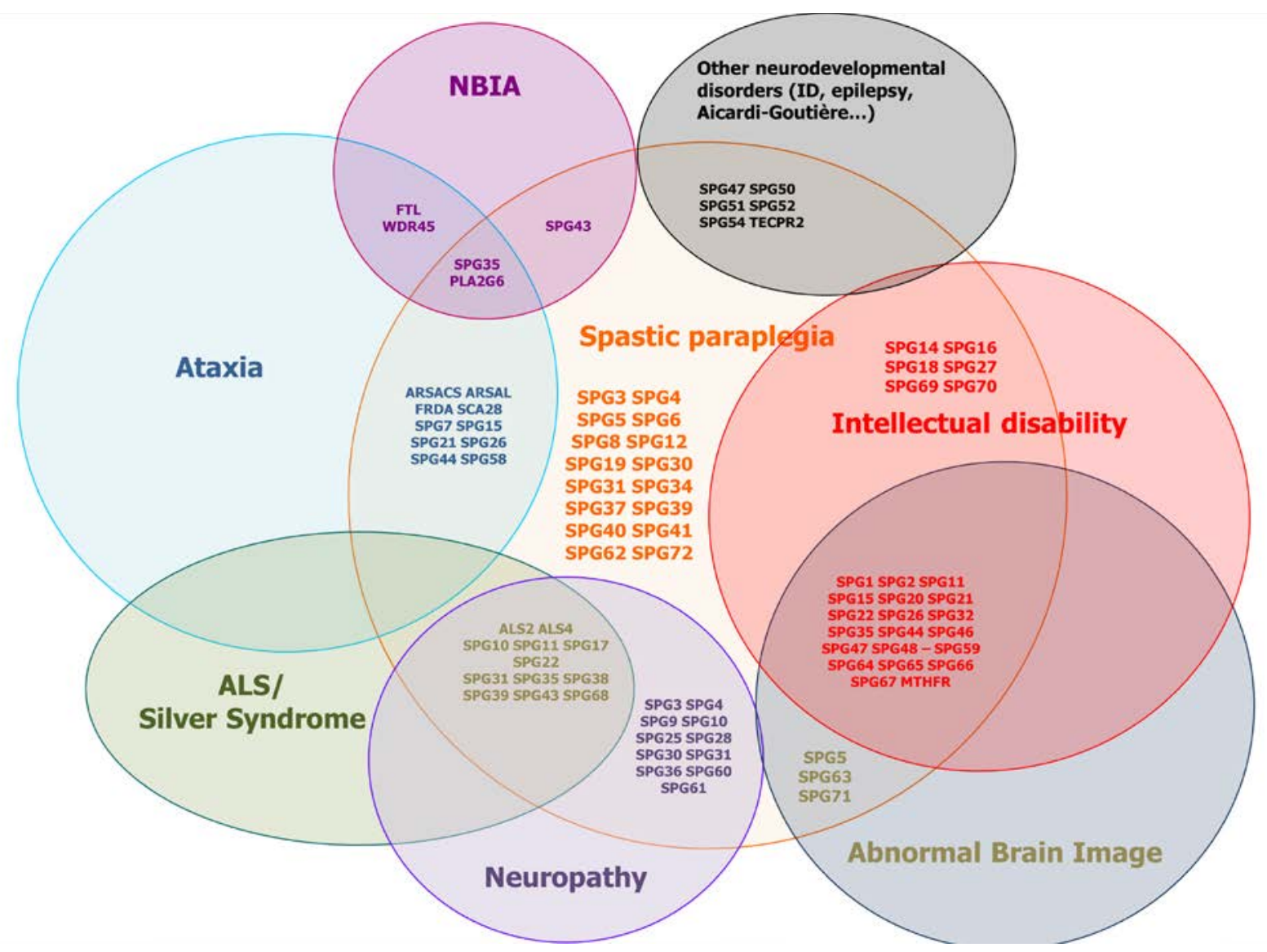


Figure 2. Overview of the pathophysiological mechanisms involved in HSP

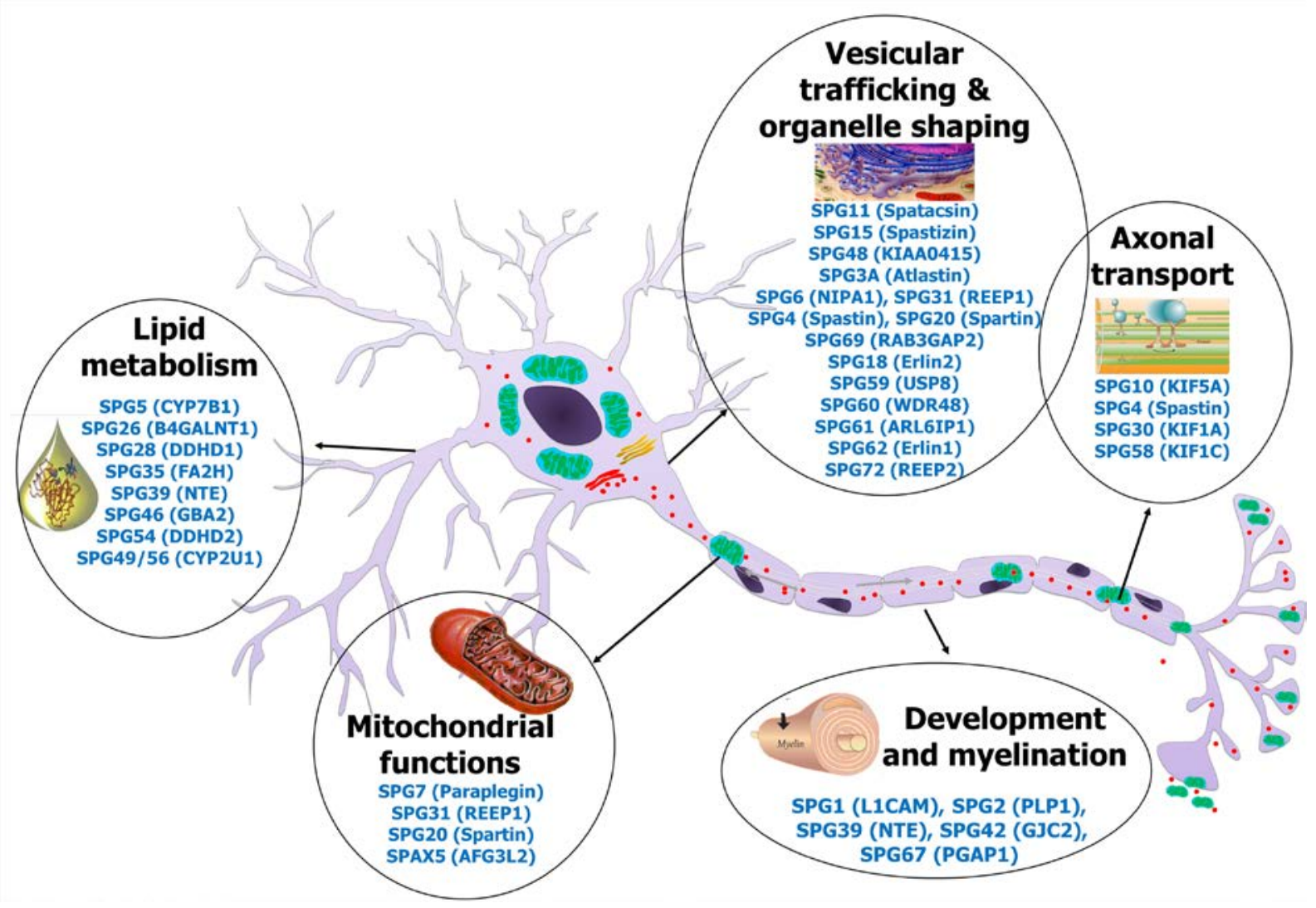


Table 1. Differential diagnoses of HSP

\begin{tabular}{|c|c|c|c|}
\hline Metabolic disorders & Structural damage & Autoimmune and infectious diseases & Other degenerative diseases \\
\hline Abetalipoproteinaemia & Cerebral palsy & Myelitis & Motoneuron disease \\
\hline Arginase Deficiency & Chiari malformation & HTLV1 & SCA \\
\hline Krabbe's disease & Atlanto-axial subluxation & HIV & Spastic ataxias \\
\hline Adrenoleucodystrophy & Cervical spine degeneration & Syphilis & \\
\hline GM1/GM2 gangliosidosis & CNS tumor & Multiple sclerosis & \\
\hline Gaucher disease & Dural arteriovenous malformation & & \\
\hline \multicolumn{4}{|l|}{ Vitamin deficiency (B12, E) } \\
\hline \multicolumn{4}{|l|}{ MTHFR deficiency } \\
\hline \multicolumn{4}{|l|}{ Copper deficiency } \\
\hline Lathyrism & & & \\
\hline
\end{tabular}




\section{L-dopa-responsive dystonia}

HTLV1: human T-cell leukemia virus 1; HIV: Human immunodeficiency virus; MTHFR: methylenetetrahydrofolate reductase; SCA: Spinocerebellar Ataxia; CNS: central nervous system; L-dopa: Levodopa 
Table 2. Loci and genes involved in HSP and their associated phenotypes.

\begin{tabular}{|c|c|c|c|c|c|c|c|c|c|c|c|}
\hline Inheritance & \begin{tabular}{|c} 
SPG \\
(NCBI)
\end{tabular} & $\begin{array}{l}\text { SPG } \\
\text { (HGNC) }\end{array}$ & Gene & $\begin{array}{c}\text { Chromoso } \\
\text { me }\end{array}$ & Protein (Uniprot) & Reference & Frequency & $\begin{array}{c}\text { Age at } \\
\text { onset } \\
\text { (yrs) }\end{array}$ & $\begin{array}{c}\text { Pure (P) / } \\
\text { Complex } \\
\text { (C) }\end{array}$ & $\begin{array}{l}\text { Associated clinical features } \\
\text { OMIM } \mathbf{N}^{\circ}\end{array}$ & MRI \\
\hline $\mathrm{AD}(\mathrm{AR})$ & SPG3A & $\begin{array}{l}\text { SPG3 } \\
\text { SPG3A }\end{array}$ & ATL1 & $14 q 22.1$ & Atlastin 1 & 40 & $\begin{array}{l}\text { Second most } \\
\text { frequent AD } \\
\text { form, most } \\
\text { frequent } \\
\text { form in } \\
\text { early-onset } \\
\text { [5-20\%] }\end{array}$ & $\begin{array}{l}\text { Usually } \\
\text { before age } \\
10[1-51]\end{array}$ & $\mathrm{P}(\mathrm{C})$ & $\begin{array}{l}\text { Rarely: axonal neuropathy } \\
182600\end{array}$ & Normal \\
\hline $\mathrm{AD}$ & SPG4 & SPG4 & SPAST & $2 p 22.3$ & Spastin & 33 & \begin{tabular}{|c} 
Most \\
frequent AD \\
form [10- \\
$40 \%]$
\end{tabular} & $\begin{array}{c}\text { Mean age } \\
\text { at onset: } \\
30 \text { years } \\
{[1-80]}\end{array}$ & $\mathrm{P}(\mathrm{C})$ & $\begin{array}{c}\text { rarely: neuropathy, cognitive } \\
\text { impariment } \\
182601\end{array}$ & Normal \\
\hline $\mathrm{AD}$ & SPG6 & SPG6 & NIPA1 & $15 q 11.2$ & NIPA1 & 64 & Rare & $\begin{array}{l}\text { Variable } \\
\text { [8-37] }\end{array}$ & $\mathrm{P}(\mathrm{C})$ & $\begin{array}{l}\text { rarely: neuropathy } \\
600363\end{array}$ & Normal \\
\hline $\mathrm{AD}$ & SPG8 & SPG8 & KIAA0196 & $8 \mathrm{q} 24.13$ & Strumpellin & 165 & Rare & $\begin{array}{l}\text { Variable } \\
\text { [18-60] }\end{array}$ & $\mathrm{P}(\mathrm{C})$ & 603563 & Normal \\
\hline $\mathrm{AD}$ & SPG9 & SPG9 & - & $\begin{array}{l}10 \mathrm{q} 23.3- \\
\mathrm{q} 24.2\end{array}$ & & 166 & 2 families & $\begin{array}{c}\text { Variable } \\
\text { [1-30], } \\
\text { possible } \\
\text { anticipatio } \\
\text { n }\end{array}$ & $\mathrm{P}$ or $\mathrm{C}$ & $\begin{array}{l}\text { Bilateral cataracts, gastro- } \\
\text { esophageal reflux with } \\
\text { persistent vomiting, } \\
\text { peripheral motor and sensory } \\
\text { neuropathy, amyotrophy. } \\
601162 \\
\end{array}$ & Normal \\
\hline $\mathrm{AD}$ & SPG10 & SPG10 & KIF5A & $12 q 13.3$ & $\begin{array}{l}\text { Kinesin heavy chain } \\
\text { isoform 5A (KIF5A) }\end{array}$ & 55 & $2-10 \%$ & $\begin{array}{l}\text { Variable } \\
\text { [2-51] }\end{array}$ & $\mathrm{P}(\mathrm{C})$ & $\begin{array}{c}\text { Neuropathy, Silver syndrome } \\
604187\end{array}$ & Normal \\
\hline $\mathrm{AD}$ & SPG12 & SPG12 & RTN2 & 19q13.32 & Reticulon 2 & 146 & Rare & $\begin{array}{l}\text { Variable } \\
\text { [5-24] }\end{array}$ & $\mathrm{P}$ & 604805 & Normal \\
\hline $\mathrm{AD}$ & SPG13 & SPG13 & HSPD1 & $2 \mathrm{q} 33.1$ & Chaperonin & 167 & 1 family & $\begin{array}{l}\text { variable } \\
{[17-68]}\end{array}$ & $\mathrm{P}$ & 605280 & Normal \\
\hline $\mathrm{AD}$ & SPG17 & SPG17 & $B S C L 2$ & $11 q 12.3$ & Seipin & 110 & Rare & $\begin{array}{l}\text { Variable } \\
\text { [2-60] }\end{array}$ & $\mathrm{C}(\mathrm{P})$ & $\begin{array}{l}\text { Silver syndrome, neuropathy } \\
270685\end{array}$ & Normal \\
\hline
\end{tabular}




\begin{tabular}{|c|c|c|c|c|c|c|c|c|c|c|c|}
\hline $\mathrm{AD}$ & SPG19 & SPG19 & - & 9q33-q34 & & 168 & 1 family & $\begin{array}{c}\text { Adulthood } \\
\text { [36-55] }\end{array}$ & $\mathrm{P}$ & 607152 & Normal \\
\hline $\mathrm{AD}$ & SPG29 & SPG29 & - & 1p31.1-21.1 & & 169 & 1 family & Infancy & C & $\begin{array}{c}\text { Neonatal hyperbilirubinemia, } \\
\text { hearing impairement due to } \\
\text { auditory neuropathy, } \\
\text { persistent vomiting due to } \\
\text { hiatal hernia. } \\
609727 \\
\end{array}$ & Normal \\
\hline $\mathrm{AD}$ & SPG31 & SPG31 & REEP1 & 2p11.2 & $\begin{array}{l}\text { Receptor expression- } \\
\text { enhancing protein } 1 \\
\text { (REEP1) }\end{array}$ & 53 & $2-10 \%$ & $\begin{array}{c}\text { Variable } \\
\text { [2-45] }\end{array}$ & $\mathrm{P}(\mathrm{C})$ & $\begin{array}{c}\text { Neuropathy } \\
610250\end{array}$ & Normal \\
\hline $\mathrm{AD}$ & SPG33 & SPG33 & ZFYVE27 & $10 \mathrm{q} 24.2$ & Protrudine & 170 & 1 family & $\begin{array}{l}\text { Adulthood } \\
\text { [42-50] }\end{array}$ & $\mathrm{P}$ & 610248 & \\
\hline $\mathrm{AD}$ & SPG36 & SPG36 & - & 12q23-24 & & 171 & 1 family & $\begin{array}{l}\text { Variable } \\
\text { [14-33] }\end{array}$ & $\mathrm{C}$ & $\begin{array}{c}\text { Peripheral sensorymotor } \\
\text { neuropathy } \\
613096 \\
\end{array}$ & Normal \\
\hline $\mathrm{AD}$ & SPG37 & SPG37 & - & $\begin{array}{c}\text { 8p21.1- } \\
\text { q13.3 }\end{array}$ & & 172 & 1 family & $\begin{array}{l}\text { Variable } \\
\text { [8-60] }\end{array}$ & $\mathrm{P}$ & 611945 & Normal \\
\hline $\mathrm{AD}$ & SPG38 & SPG38 & - & 4p16-p15 & & 173 & 1 family & [16-19] & $\mathrm{P}$ & 612335 & \\
\hline $\mathrm{AD}$ & SPG41 & SPG41 & - & $\begin{array}{c}\text { 11p14.1- } \\
\text { 11p.2 }\end{array}$ & & 174 & 1 family & $\begin{array}{c}\text { Mean: } 17 \\
\text { yrs }\end{array}$ & $\mathrm{P}$ & 613364 & Normal \\
\hline $\mathrm{AD}$ & SPG42 & SPG42 & SLC33A1 & $3 q 25.31$ & $\begin{array}{l}\text { Acetyl-coenzyme A } \\
\text { transporter 1 } \\
\text { (SLC33A1) }\end{array}$ & 175 & 1 family & $\begin{array}{c}\text { Variable } \\
\text { [4-42] }\end{array}$ & $\mathrm{P}$ & 612539 & Normal \\
\hline AR & SPG5 & SPG5A & CYP7B1 & $8 q 12.3$ & $\begin{array}{c}25- \\
\text { hydroxycholesterol } \\
\text { 7-alpha-hydroxylase }\end{array}$ & 163 & $3-8 \%$ & $\begin{array}{c}\text { Variable } \\
\text { [4-47] }\end{array}$ & $\mathrm{P}$ or $\mathrm{C}$ & $\begin{array}{l}\text { Cerebellar sign, nystagmus, } \\
\text { amyotrophy, cognitive } \\
\text { impairment } \\
270800 \\
\end{array}$ & Normal or WMA \\
\hline AR & SPG7 & SPG7 & SPG7 & $16 \mathrm{q} 24.3$ & Paraplegin & 22 & $2-10 \%$ & $\begin{array}{c}\text { Variable } \\
\text { [4-42] }\end{array}$ & $\mathrm{P}$ or $\mathrm{C}$ & $\begin{array}{c}\text { optic neuropathy, cerebellar } \\
\text { ataxia. } \\
607259\end{array}$ & Cerebellar atrophy \\
\hline
\end{tabular}




\begin{tabular}{|c|c|c|c|c|c|c|c|c|c|c|c|}
\hline $\mathrm{AR}$ & SPG11 & SPG11 & SPG11 & 15q21.1 & Spatacsin & 97 & $\begin{array}{l}\text { Most } \\
\text { frequent } \\
\text { form of } \\
\text { HSP-TCC } \\
(60 \%), \text { most } \\
\text { frequent AR } \\
\text { form (20\%) }\end{array}$ & $\begin{array}{c}\text { Early with } \\
\text { variability } \\
\text { [1-30] }\end{array}$ & $\mathrm{C}$ & $\begin{array}{c}\text { Cognitive decline, } \\
\text { neuropathy, retinopathy, } \\
\text { (Kjellin syndrome), cerebellar } \\
\text { signs, ALS } \\
604360\end{array}$ & $\begin{array}{l}\text { TCC, WMA, } \\
\text { cerebellar atrophy }\end{array}$ \\
\hline $\mathrm{AR}$ & SPG14 & SPG14 & - & $3 q 27-q 28$ & & 176 & 1 family & & $\mathrm{C}$ & $\begin{array}{c}\text { Distal motor neuropathy, } \\
\text { mild mental retardation, } \\
\text { visual agnosia, memory } \\
\text { deficiency } \\
605229 \\
\end{array}$ & Normal \\
\hline $\mathrm{AR}$ & SPG15 & SPG15 & ZFYVE26 & 14q24.1 & Spastizin & 177 & \begin{tabular}{|c|} 
HSP-TCC \\
[5-11\%], \\
ARHSP [2- \\
$5 \%]$
\end{tabular} & $\begin{array}{c}\text { Early [4- } \\
19]\end{array}$ & $\mathrm{C}$ & $\begin{array}{c}\text { Cognitive decline, } \\
\text { neuropathy, retinopathy, } \\
\text { (Kjellin syndrome), cerebellar } \\
\text { signs } \\
270700\end{array}$ & $\begin{array}{l}\text { TCC, WMA, } \\
\text { cerebellar atrophy }\end{array}$ \\
\hline $\mathrm{AR}$ & SPG18 & SPG18 & ERLIN2 & 8p11.23 & Erlin 2 & 178 & Rare & Infancy & $\mathrm{C}$ & $\begin{array}{c}\text { Intellectual disability, } \\
\text { contracture, juvenile primary } \\
\text { lateral sclerosis } \\
611225\end{array}$ & Normal \\
\hline AR & SPG20 & SPG20 & SPG20 & $13 q 12.3$ & Spartin & 179 & $\begin{array}{l}\text { Rare, } \\
\text { founder } \\
\text { effect in } \\
\text { Amish and } \\
\text { Omani } \\
\text { populations }\end{array}$ & Infancy & $\mathrm{C}$ & $\begin{array}{l}\text { Troyer Syndrome: } \\
\text { Dysarthria, distal amyotrophy } \\
\text { in the hands and feet, } \\
\text { cerebellar sign, mild } \\
\text { intellectual deficit and various } \\
\text { skeletal abnormalites } \\
\text { especially short stature } \\
275900\end{array}$ & WMA \\
\hline AR & SPG21 & SPG21 & $\begin{array}{c}\text { SPG21 } \\
\text { (ACP33) }\end{array}$ & $15 q 22.31$ & Maspardin & 91 & $\begin{array}{c}\text { Rare, } \\
\text { founder } \\
\text { effect in the } \\
\text { Ohio Amish } \\
\text { population }\end{array}$ & $\begin{array}{l}\text { Adulthood } \\
\text {, with } \\
\text { variability }\end{array}$ & C & $\begin{array}{c}\text { Mast Syndrome : Speech } \\
\text { decline leading to akinetic } \\
\text { mutism,psychotic episodes, } \\
\text { cognitive decline and } \\
\text { cerebellar dysfunction } \\
248900\end{array}$ & TCC, WMA \\
\hline
\end{tabular}




\begin{tabular}{|c|c|c|c|c|c|c|c|c|c|c|c|}
\hline AR & SPG23 & SPG23 & - & 1q24-q32 & & 180 & Rare & Infancy & C & $\begin{array}{l}\text { Lison syndrome : Abnormal } \\
\text { pigmentation of the skin and } \\
\text { hair. Some cases present } \\
\text { facial dysmorphisms, skeletal } \\
\text { deformities, mental } \\
\text { retardation or sensorimotor } \\
\text { neuropathy. } \\
270750 \\
\end{array}$ & $\begin{array}{l}\text { Normal or slight } \\
\text { enlargement of the } \\
\text { ventricules }\end{array}$ \\
\hline AR & SPG24 & SPG24 & - & 13q14 & & 181 & 1 family & Infancy & $\mathrm{P}$ & 607584 & Normal \\
\hline AR & SPG25 & SPG25 & - & $6 q 23-24.1$ & & 182 & 1 family & $\begin{array}{c}\text { Adulthood } \\
\text { [30-46] }\end{array}$ & C & $\begin{array}{l}\text { Mild sensorimotor } \\
\text { neuropathy. } \\
608220\end{array}$ & $\begin{array}{l}\text { Spinal disc } \\
\text { herniations }\end{array}$ \\
\hline AR & SPG26 & SPG26 & $\begin{array}{c}\text { B4GALNT } \\
1\end{array}$ & 12q13.3 & $\begin{array}{l}\text { Beta-1,4 N- } \\
\text { acetylgalactosaminylt } \\
\text { ransferase } 1\end{array}$ & 183 & Rare & $\begin{array}{c}\text { Early with } \\
\text { variability } \\
\text { [2-19] }\end{array}$ & C & $\begin{array}{c}\text { Intellectual disability, } \\
\text { cerebellar ataxia, peripheral } \\
\text { neuropathy and one family } \\
\text { present behavorial problems } \\
609195\end{array}$ & $\begin{array}{l}\text { Normal or after long } \\
\text { disease duration } \\
\text { crtical and } \\
\text { subcortical atrophy } \\
\text { and/or white matter } \\
\text { hyperintensities }\end{array}$ \\
\hline AR & SPG27 & SPG27 & - & $\begin{array}{c}\text { 10q22.1- } \\
\text { q24.1 }\end{array}$ & & 184 & Rare & $\begin{array}{c}\text { Variable } \\
\text { [2-45] } \\
\text { C 2-7 }\end{array}$ & $\mathrm{P}$ or $\mathrm{C}$ & $\begin{array}{c}\text { Sensorimotor polyneuropathy } \\
\text { and sometimes with mental } \\
\text { retardation, cerebellar signs } \\
\text { and squeletal abnormalities } \\
609041\end{array}$ & $\begin{array}{l}\text { Normal or mild } \\
\text { cortical } \\
\text { and cerebellar } \\
\text { atrophy }\end{array}$ \\
\hline AR & SPG28 & SPG28 & $D D H D 1$ & 14q22.1 & $\begin{array}{l}\text { Phospholipase } \\
\text { DDHD1 }\end{array}$ & 87 & Rare & \begin{tabular}{|c} 
Early [7- \\
$15]$
\end{tabular} & $\mathrm{P}$ or $\mathrm{C}$ & $\begin{array}{c}\text { Pure or complex with } \\
\text { cerebellar occulomotor } \\
\text { disturbnce or axonal } \\
\text { neuropathy } \\
609340\end{array}$ & Normal \\
\hline
\end{tabular}




\begin{tabular}{|c|c|c|c|c|c|c|c|c|c|c|c|}
\hline AR & SPG30 & SPG30 & KIF1A & $2 q 37.3$ & $\begin{array}{c}\text { Kinesin-like protein } \\
\text { KIF1A }\end{array}$ & 84,85 & Rare & $\begin{array}{l}\text { Variable } \\
\text { [10-39] }\end{array}$ & $\mathrm{P}$ or $\mathrm{C}$ & $\begin{array}{c}\text { Pure or Complex with sensory } \\
\text { neuropathy and cerebellar } \\
\text { ataxia } \\
610357\end{array}$ & $\begin{array}{c}\text { Normal or cerebellaı } \\
\text { atrophy }\end{array}$ \\
\hline AR & SPG32 & SPG32 & - & 14q12-q21 & & 185 & 1 family & $6-7$ & $\mathrm{C}$ & $\begin{array}{l}\text { Mild mental retardation. } \\
\quad 611252\end{array}$ & $\begin{array}{c}\text { Cerebellar atrophy, } \\
\text { pontine dysraphia, } \\
\text { moderate TCC }\end{array}$ \\
\hline AR & SPG35 & SPG35 & $\mathrm{FA} 2 \mathrm{H}$ & 16q23.1 & $\begin{array}{l}\text { Fatty acid 2- } \\
\text { hydroxylase }\end{array}$ & 96 & Rare & $\begin{array}{l}2-17 \\
\text { one } \\
\text { family } \\
\text { with late } \\
\text { onset }\end{array}$ & C & $\begin{array}{c}\text { Dystonia, LL amyotrophy, } \\
\text { seizures, cerebellar signs, } \\
\text { cognitive declin and optic } \\
\text { atrophy. } \\
612319\end{array}$ & $\begin{array}{l}\text { Leukodystrophy, } \\
\text { hypointensities of } \\
\text { globus pallidus, } \\
\text { TCC, cerebellar } \\
\text { atrophy. }\end{array}$ \\
\hline AR & SPG39 & SPG39 & PNPLA6 & 19p13.2 & $\begin{array}{l}\text { Neuropathy target } \\
\text { esterase (NTE) }\end{array}$ & 186 & Rare & $\begin{array}{l}\text { Early with } \\
\text { variability }\end{array}$ & C & $\begin{array}{l}\text { Muscle wasting and motor } \\
\text { axonopathy of the LL and UL } \\
612020\end{array}$ & Normal \\
\hline AR & SPG43 & SPG43 & $\begin{array}{c}\text { C19ORF1 } \\
2\end{array}$ & $\begin{array}{l}\text { 19p13.11- } \\
\text { q12 }\end{array}$ & Protein C19orf12 & 187 & 1 family & $\begin{array}{c}\text { Childhood } \\
\text { [7-12] }\end{array}$ & C & $\begin{array}{c}\text { Neuropathy and severe } \\
\text { atrophy and decreased } \\
\text { sensation in the arms and legs } \\
615043 \\
\end{array}$ & Normal \\
\hline AR & SPG44 & SPG44 & GJC2 & $1 \mathrm{q} 42.13$ & $\begin{array}{l}\text { Gap junction gamma- } \\
2 \text { protein }\end{array}$ & 92 & 1 family & $\begin{array}{l}\text { Early with } \\
\text { variability }\end{array}$ & $\mathrm{C}$ & $\begin{array}{l}\text { Dysarthria, cereballar ataxia, } \\
\text { mental impairement. } \\
613206\end{array}$ & WMA \\
\hline AR & SPG45 & SPG45 & - & $\begin{array}{l}\text { 10q24.3- } \\
\text { q25.1 }\end{array}$ & & 188 & 1 family & Infancy & $\mathrm{C}$ & $\begin{array}{l}\text { Mental retardation and } \\
\text { occular signs } \\
613162\end{array}$ & \\
\hline AR & SPG46 & SPG46 & GBA2 & 9p13.3 & $\begin{array}{c}\text { Non-lysosomal } \\
\text { glucosylceramidase }\end{array}$ & 90 & Rare & $\begin{array}{c}\text { Early [1- } \\
16]\end{array}$ & $\mathrm{C}$ & $\begin{array}{c}\text { Cerebellar ataxia, cataract and } \\
\text { mental impairment. } \\
614409\end{array}$ & $\begin{array}{l}\text { TCC, WMA, } \\
\text { cerebellar atrophy }\end{array}$ \\
\hline AR & SPG47 & SPG47 & $A P 4 B 1$ & $1 \mathrm{p} 13.2$ & $\begin{array}{l}\text { AP-4 complex } \\
\text { subunit beta-1 }\end{array}$ & 93 & Rare & Infancy & C & $\begin{array}{l}\text { Severe intellectual disability, } \\
\text { absent speech, shy character, } \\
\text { stereotypic laughter, muscular } \\
\text { hypotonia, microcephaly, foot } \\
\text { dformity, decreased muscle } \\
\text { mass and growth retardation }\end{array}$ & TCC, WMA \\
\hline
\end{tabular}




\begin{tabular}{|c|c|c|c|c|c|c|c|c|c|c|c|}
\hline & & & & & & & & & & 614066 & \\
\hline AR & SPG48 & SPG48 & AP5Z1 & $7 \mathrm{p} 22.1$ & $\begin{array}{l}\text { AP-5 complex } \\
\text { subunit zeta-1 }\end{array}$ & 189 & Rare & $\begin{array}{l}\text { Variale } \\
{[2-50]}\end{array}$ & P or $\mathrm{C}$ & $\begin{array}{c}\text { Pure or complex with } \\
\text { cognitive impairment or } \\
\text { mental retardation } \\
613647\end{array}$ & $\begin{array}{c}\text { Normal or TCC, } \\
\text { WMA }\end{array}$ \\
\hline AR & SPG56 & SPG49 & CYP2U1 & $4 q 25$ & $\begin{array}{c}\text { Cytochrome P450 } \\
\text { 2U1 }\end{array}$ & 87 & Rare & Infancy & $\mathrm{P}$ or $\mathrm{C}$ & $\begin{array}{c}\text { Pure or complex with mental } \\
\text { impairement, dysarthria, } \\
\text { dystonia, infraclinical axonal } \\
\text { neuropathy } \\
615030\end{array}$ & $\begin{array}{l}\text { Normal or TCC, } \\
\text { WMA, basal } \\
\text { ganglion } \\
\text { calcification }\end{array}$ \\
\hline AR & SPG49 & No SPG & TECPR2 & $14 q 32.31$ & $\begin{array}{l}\text { Tectonin beta- } \\
\text { propeller repeat- } \\
\text { containing protein } 2\end{array}$ & 190 & Rare & Infancy & C & $\begin{array}{c}\text { Severe intellectualdisability, } \\
\text { rigid ataxic gait, } \\
\text { brachycephalic microcephaly, } \\
\text { fluacting central } \\
\text { hypoventilation, } \\
\text { gastresophageal reflux } \\
\text { disease, wake apnea, } \\
\text { areflexia, dysmorphic features } \\
\text { 615031 } \\
\end{array}$ & $\begin{array}{l}\text { Ventriculomegaly, } \\
\text { TCC, cerebellar } \\
\text { atrophy }\end{array}$ \\
\hline AR & SPG50 & SPG50 & AP4M1 & 7q22.1 & $\begin{array}{l}\text { AP-4 complex } \\
\text { subunit mu-1 }\end{array}$ & 191 & Rare & Infancy & C & $\begin{array}{c}\text { Tetraplegic cerebral palsy, } \\
\text { mental retardation, } \\
612936\end{array}$ & $\begin{array}{l}\text { WMA, cereballar } \\
\text { atrophy }\end{array}$ \\
\hline AR & SPG51 & SPG51 & AP4E1 & 15q21.2 & $\begin{array}{c}\text { AP-4 complex } \\
\text { subunit epsilon-1 }\end{array}$ & 93,192 & Rare & Infancy & C & $\begin{array}{c}\text { Neonatal hypotonia } \\
\text { progressing to hypertonia, } \\
\text { spasticity, mental retardation, } \\
\text { poor or absent speech } \\
\text { development } \\
613744\end{array}$ & \\
\hline
\end{tabular}




\begin{tabular}{|c|c|c|c|c|c|c|c|c|c|c|c|}
\hline $\mathrm{AR}$ & SPG52 & SPG52 & AP4S1 & $14 q 12$ & $\begin{array}{l}\text { AP-4 complex } \\
\text { subunit sigma-1 }\end{array}$ & 93 & 1 family & Infancy & C & $\begin{array}{c}\text { Severe intellectual disability, } \\
\text { absent speech, shy character, } \\
\text { stereotypic laughter, muscular } \\
\text { hypotonia, microcephaly, foot } \\
\text { dformity, decreased muscle } \\
\text { mass and growth retardation } \\
614067 \\
\end{array}$ & \\
\hline AR & SPG53 & SPG53 & VPS37A & 8p22 & $\begin{array}{l}\text { Vacuolar protein } \\
\text { sorting } 37 \text { homolos A }\end{array}$ & 193 & Rare & Infancy & $\mathrm{C}$ & $\begin{array}{c}\text { Developmental and motor } \\
\text { delay, delays in cognition and } \\
\text { speech, marked kyphosis } \\
614898\end{array}$ & $\begin{array}{l}\text { Normal or WMA, } \\
\text { mild } \\
\text { ventriculomegalgy }\end{array}$ \\
\hline AR & SPG54 & SPG54 & DDHD2 & 8p11.23 & $\begin{array}{l}\text { Phospholipase } \\
\text { DDHD2 }\end{array}$ & 94 & Rare & Infancy & $\mathrm{C}$ & $\begin{array}{c}\text { Intellectual disability or } \\
\text { developmental delay, } \\
\text { dysarthria cerebellar sign, } \\
\text { short stature } \\
615033\end{array}$ & TCC, WMA \\
\hline $\mathrm{AR}$ & SPG55 & SPG55 & $\begin{array}{c}\text { C12ORF6 } \\
5\end{array}$ & $12 \mathrm{q} 24.31$ & $\begin{array}{l}\text { Probable peptide } \\
\text { chain release factor } \\
\text { C12orf65, } \\
\text { mitochondrial }\end{array}$ & 194 & Rare & $\begin{array}{c}\text { Childhood } \\
\text { [2-7] }\end{array}$ & $\mathrm{C}$ & $\begin{array}{l}\text { Optic atrophy, muscle } \\
\text { atrophy and neuropathy or } \\
\text { intellectual disability, } \\
\text { neuropathy, ophtalmoplegia } \\
615035\end{array}$ & $\begin{array}{l}\text { Normal or Thin } \\
\text { corpus callosum and } \\
\text { white matters } \\
\text { abnormalities }\end{array}$ \\
\hline $\mathrm{AR}$ & SPG57 & SPG57 & TFG & 3q12.2 & Protein TFG & $\begin{array}{l}195 \\
196\end{array}$ & 1 family & Infancy & $\mathrm{C}$ & $\begin{array}{c}\text { Optic atrophy, axonal } \\
\text { demyelinating motor } \\
\text { neuropathy. } \\
615658 \\
\end{array}$ & Normal \\
\hline $\mathrm{AR}$ & SPG58 & SPG58 & KIF1C & 17p13.2 & $\begin{array}{l}\text { Kinesin-like protein } \\
\text { KIF1C }\end{array}$ & $\begin{array}{c}125 \\
1\end{array}$ & Rare & Infancy & $\mathrm{P}$ or $\mathrm{C}$ & $\begin{array}{l}\text { Pure or complex with ataxia, } \\
\text { dysarthria, extrapyramidal } \\
\text { chorea, hypodonita, } \\
\text { developmental delay or } \\
\text { mental retardation }\end{array}$ & Normal or WMA \\
\hline AR & SPG59 & SPG59 & USP8 & $15 \mathrm{q} 21.2$ & $\begin{array}{l}\text { Ubiquitin carboxyl- } \\
\text { terminal hydrolase } 8\end{array}$ & 1 & 1 family & Infancy & C & $\begin{array}{l}\text { Nystagmus, pes equinovarus, } \\
\text { mild mental retardation }\end{array}$ & Normal \\
\hline AR & SPG60 & & WDR48 & 3p22.2 & $\begin{array}{l}\text { WD repeat- } \\
\text { containing protein } 48\end{array}$ & 1 & 1 family & Infancy & $\mathrm{C}$ & Nystagmus, neuropathy & Normal \\
\hline
\end{tabular}




\begin{tabular}{|c|c|c|c|c|c|c|c|c|c|c|c|}
\hline AR & SPG61 & SPG61 & ARL6IP1 & 16p12.3 & $\begin{array}{l}\text { ADP-ribosylation } \\
\text { factor-like protein } 6- \\
\text { interacting protein } 1\end{array}$ & 1 & 1 family & Infancy & C & $\begin{array}{l}\text { Motor and sensory } \\
\text { polyneuropathy with } \\
\text { acromutilation } \\
615685 \\
\end{array}$ & $\begin{array}{l}\text { Normal or mild } \\
\text { dilatation of lateral } \\
\text { ventricules }\end{array}$ \\
\hline AR & SPG62 & SPG62 & ERLIN1 & $10 \mathrm{q} 24.31$ & Erlin 1 & 1 & Rare & Infancy & $\mathrm{P}$ & & Normal \\
\hline AR & SPG63 & SPG63 & AMPD2 & 1p13.3 & AMP deaminase 2 & 1 & 1 family & Infancy & $\mathrm{C}$ & $\begin{array}{c}\text { Short stature } \\
\quad 615686\end{array}$ & TCC, WMA \\
\hline AR & SPG64 & SPG64 & ENTPD1 & 10q24.1 & $\begin{array}{l}\text { Ectonucleosidase } \\
\text { triphosphate } \\
\text { diphosphorilase } 1\end{array}$ & 1 & Rare & Infancy & $\mathrm{C}$ & $\begin{array}{c}\text { Amyotrophy, cerebellar sign, } \\
\text { moderate intellectual } \\
\text { disability, agressiveness, } \\
\text { delayed puberty, } \\
\text { microcephaly } \\
615683\end{array}$ & WMA \\
\hline AR & SPG65 & SPG65 & NT5C2 & $\begin{array}{c}10 \mathrm{q} 24.32 \\
\mathrm{q} 24.33\end{array}$ & $\begin{array}{l}\text { Cytosolic purine 5'- } \\
\text { nucleotidase }\end{array}$ & 1 & Rare & Infancy & $\mathrm{P}$ or $\mathrm{C}$ & $\begin{array}{c}\text { Amyotrophy, pes } \\
\text { equinovarus, learning } \\
\text { disability } \\
613162 \\
\end{array}$ & TCC, WMA \\
\hline AR & SPG66 & SPG66 & ARSI & $5 q 32$ & Arylsulfatase I & 1 & 1 family & Infancy & $\mathrm{C}$ & $\begin{array}{c}\text { Amyotrophy, pes } \\
\text { equinovarus, sensory/motor } \\
\text { polyneuropathy }\end{array}$ & $\begin{array}{l}\text { TCC, cerebellar } \\
\text { hypoplasia }\end{array}$ \\
\hline AR & SPG67 & SPG67 & $P G A P 1$ & $2 \mathrm{q} 33.1$ & $\begin{array}{l}\text { GPI inositol- } \\
\text { deacylase }\end{array}$ & 1 & 1 family & Infancy & C & Amyotrophy & $\begin{array}{c}\text { ACC, vermis } \\
\text { hypolasia, deffective } \\
\text { myelination, } \\
\text { prominent cortical } \\
\text { sulci \& widened } \\
\text { sylvian fissures }\end{array}$ \\
\hline AR & SPG68 & SPG68 & FLRT1 & 11q13.1 & $\begin{array}{l}\text { Leucine-rich repeat } \\
\text { transmembrane } \\
\text { protein FLRT1 }\end{array}$ & 1 & 1 family & Infancy & $\mathrm{C}$ & $\begin{array}{c}\text { Optic atrophy, nystagmus, } \\
\text { mild amyotrophy, péripheral } \\
\text { neuropathy }\end{array}$ & Normal \\
\hline
\end{tabular}




\begin{tabular}{|c|c|c|c|c|c|c|c|c|c|c|c|}
\hline AR & SPG69 & SPG69 & $\begin{array}{c}\text { RAB3GAP } \\
2\end{array}$ & $1 \mathrm{q} 31$ & $\begin{array}{c}\text { Rab3 GTPase- } \\
\text { activating protein } \\
\text { non-catalytic subunit }\end{array}$ & 1 & 1 family & Infancy & C & $\begin{array}{c}\text { Dysarthria, cataract, } \\
\text { deafness, intellectual } \\
\text { disability }\end{array}$ & Normal \\
\hline AR & SPG70 & SPG70 & MARS & 12q13.3 & $\begin{array}{l}\text { Methionine--tRNA } \\
\text { ligase, cytoplasmic }\end{array}$ & 1 & 1 family & Infancy & $\mathrm{C}$ & $\begin{array}{c}\text { Amyotrophy, bilateral achilles } \\
\text { contractures }\end{array}$ & \\
\hline AR & SPG71 & SPG71 & ZFR & $5 p 13.3$ & $\begin{array}{l}\text { Zinc finger RNA- } \\
\text { binding protein }\end{array}$ & 1 & 1 family & Infancy & $\mathrm{P}$ & & TCC \\
\hline $\begin{array}{l}\mathrm{AD} \\
\mathrm{AR}\end{array}$ & SPG72 & SPG72 & REEP2 & $5 q 31.2$ & $\begin{array}{l}\text { Receptor expression- } \\
\text { enhancing protein } 2 \\
\text { (REEP2) }\end{array}$ & 26 & Rare & Infancy & $\mathrm{P}$ & 615625 & \\
\hline AR & - & - & LYST & $1 q 42.3$ & $\begin{array}{c}\text { Lysosomal- } \\
\text { trafficking regulator }\end{array}$ & 197 & 1 family & $\begin{array}{l}\text { Late [48- } \\
58 \text { 58] }\end{array}$ & $\mathrm{C}$ & \begin{tabular}{|c} 
Cerebellar ataxia, peripheral \\
neuropathy Mutations in \\
this gene also cause Chediak- \\
Higashi syndrome \\
214500
\end{tabular} & Cerebellar atrophy \\
\hline AR & - & - & $M A G$ & 19q13.1 & $\begin{array}{l}\text { Myelin-associated } \\
\text { glycoprotein }\end{array}$ & 1 & 1 family & Infancy & $\mathrm{C}$ & $\begin{array}{l}\text { Cerebellar sign, nystagmus, } \\
\text { and amyotrophy }\end{array}$ & Normal \\
\hline AR & - & - & ССT5 & $5 p 15.2$ & $\begin{array}{l}\text { T-complex protein } 1 \\
\text { subunit epsilon }\end{array}$ & 198 & 1 family & Infancy & C & $\begin{array}{l}\text { mutilating sensory neuropathy } \\
256840\end{array}$ & \\
\hline AR & - & - & EXOSC3 & 9p13.2 & $\begin{array}{c}\text { Exosome component } \\
3\end{array}$ & 199, 200 & 1 family & Infancy & C & $\begin{array}{c}\text { Cognitive disability, } \\
\text { cerebellar signs, distal } \\
\text { amyotrophy } \\
\text { Mutations in this genes also } \\
\text { cause Pontocerebellar } \\
\text { hypoplasia, type 1B } \\
614678\end{array}$ & $\begin{array}{c}\text { Enlarged cisterna } \\
\text { magna, cerebellar } \\
\text { atrophy }\end{array}$ \\
\hline $\begin{array}{l}\mathrm{AD} \\
\mathrm{AR}\end{array}$ & - & - & BICD2 & 9q22.32 & $\begin{array}{l}\text { Protein bicaudal D } \\
\quad \text { homolog } 2\end{array}$ & $\begin{array}{c}201 \\
1\end{array}$ & Rare & Infancy & $\mathrm{C}$ & $\begin{array}{l}\text { Spinal muscular atrophy } \\
\text { Mutations in this gene also } \\
\text { cause Spinal muscular } \\
\text { atrophy, lower extremity- } \\
\text { predominant, 2, AD } 615290\end{array}$ & Normal \\
\hline
\end{tabular}




\begin{tabular}{|c|c|c|c|c|c|c|c|c|c|c|c|}
\hline $\mathrm{X}$ linked & SPG1 & SPG1 & L1CAM & $\mathrm{Xq} 28$ & $\begin{array}{l}\text { Neural cell adhesion } \\
\text { molecule L1 }\end{array}$ & 202 & Rare & Infancy & C & $\begin{array}{l}\text { Mutations in this gene also } \\
\text { cause MASA syndrome } \\
\text { (Mental retardation Aphasia } \\
\text { Shuffling gait and Adducted } \\
\text { thumb) or CRASH syndrom } \\
\text { (Corpus callosum hypoplasia } \\
\text { Retardation Adducted thumb } \\
\text { Spastic paraplegia and } \\
\text { Hydrocephalus) } \\
303350 \\
\end{array}$ & $\begin{array}{c}\text { ACC, } \\
\text { hydrocephalus }\end{array}$ \\
\hline $\mathrm{X}$ linked & SPG2 & SPG2 & PLP1 & $\mathrm{Xq} 22.2$ & $\begin{array}{l}\text { Myelin proteolipid } \\
\text { protein }\end{array}$ & 203 & Rare & $\begin{array}{l}\text { Infancy or } \\
\text { Childhood }\end{array}$ & $\mathrm{P}$ or $\mathrm{C}$ & $\begin{array}{c}\text { nystagmus, cerebellar } \\
\text { dysfunction, hypotonia, } \\
\text { mental retardation, dementia } \\
\text { or seizures } \\
312920\end{array}$ & WMA \\
\hline $\mathrm{X}$ linked & & SPG22 & SLC16A2 & Xq13.2 & $\begin{array}{l}\text { Monocarboxylate } \\
\text { transporter } 8\end{array}$ & 204 & Rare & Infancy & $\mathrm{C}$ & $\begin{array}{l}\text { Mutations in this gene also } \\
\text { cause Allan-Herndon-Dudley } \\
\text { syndrom : spastic } \\
\text { quadriplegia, mental } \\
\text { retardation, lack of head } \\
\text { support, central hypotonia, } \\
\text { muscle hypoplasia, dystonia, } \\
\text { ataxia } \\
300523 \\
\end{array}$ & $\begin{array}{c}\text { Delayed } \\
\text { myelination, TCC, } \\
\text { cortical atrophy }\end{array}$ \\
\hline X linked & SPG16 & SPG16 & - & $\mathrm{Xq} 11.2$ & & 205 & Rare & Infancy & $\mathrm{P}$ or $\mathrm{C}$ & $\begin{array}{c}\text { quadriplegia, motor aphasia, } \\
\text { reduced vision, mild mental } \\
\text { retardation } \\
300266 \\
\end{array}$ & Delayed myelination \\
\hline X linked & SPG34 & SPG34 & - & Xq24-q25 & & 206 & 1 family & Adulthood & $\mathrm{P}$ & 300750 & \\
\hline Mitochondrial & & & $M T-T I$ & & $\begin{array}{l}\text { Transfer RNA, } \\
\text { Mitochondrial, } \\
\text { Isoleucine }\end{array}$ & 30 & 1 family & Adulthood & $\mathrm{P}$ or $\mathrm{C}$ & $\begin{array}{c}\text { ataxia, deafness, epilepsy, } \\
\text { cardiomyopathy } \\
\text { hypogonadism }\end{array}$ & \\
\hline
\end{tabular}


\begin{tabular}{|l|l|l|l} 
& & & \\
1 family & Adulthood & P or C & axonal neuropathy, cerebellar
\end{tabular} ATPase 6 